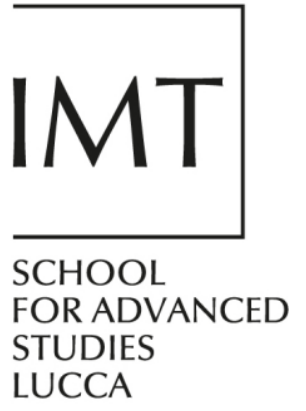

\#02

2018

SCHOOL

FOR ADVANCED

LUCCA

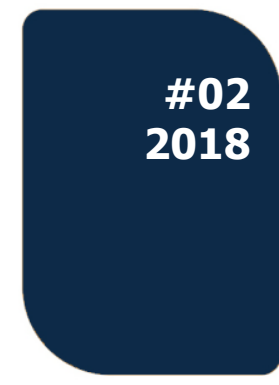

ISSN 2279-6894

IMT LUCCA EIC WORKING

PAPER SERIES 02

February 2018

RA Economics and institutional change

\title{
Cohesion Policy Meets Heterogeneous Firms
}

Loredana Fattorini

Mahdi Ghodsi

Armando Rungi 
Research Area

Economics and institutional change

\section{Cohesion Policy Meets Heterogeneous Firms}

\section{Loredana Fattorini}

IMT School for Advanced Studies Lucca

\section{Mahdi Ghodsi}

The Vienna Institute for International Economic Studies

\section{Armando Rungi}

IMT School for Advanced Studies Lucca 


\title{
Cohesion Policy Meets Heterogeneous Firms*
}

\author{
Loredana Fattorini ${ }^{\dagger} \quad$ Mahdi Ghodsi ${ }^{\ddagger} \quad$ Armando Rungi ${ }^{\S}$
}

January 2018

\begin{abstract}
In this paper, we empirically test the effects of the EU 'cohesion policy' on the performance of about 500,000 European manufacturing firms after combining regional policy data at NUTS2 level with firm-level data. In a framework of heterogeneous firms and different absorptive capacity of regions, we show that financing of 'cohesion policy' by European Regional Development Fund (ERDF) aimed at direct investments in R\&D correlates with improvement of firms' productivity in a region. Conversely, funding designed at overall Business Support correlates with negative productivity growth rates. In both cases, we registered an asymmetric impact along the firms' productivity distribution, where a stronger impact can be detected in the first quartile, i.e. less efficient firms in a region. We finally argue that considering the heterogeneity of firms allows a better assessment of the impact of 'cohesion policy' measures.
\end{abstract}

Keywords: firm performance, total factor productivity, cross-country analysis, convergence, regional policy.

JEL Classification Numbers: D22, D24, E23, F15, L25.

${ }^{*}$ We would like to thank the participants at the European Trade Study Group 2017 - Florence, as well as The Vienna Institute for International Economic Studies (wiiw) staff for their comments and discussions.

${ }^{\dagger}$ Corresponding author: mail to loredana.fattorini@imtlucca.it. IMT School for Advanced Studies Lucca, Piazza San Francesco 19, 55100 Lucca, Italy.

${ }^{\ddagger}$ Mail to: ghodsi@wiiw.ac.at. The Vienna Institute for International Economic Studies (wiiw), Rahlgasse 3, 1060 Vienna, Austria.

§Mail to: armando.rungi@imtlucca.it. IMT School for Advanced Studies Lucca, Piazza San Francesco 19, 55100 Lucca, Italy. 


\section{Introduction}

In parallel with the European integration, a 'cohesion policy' has been developed to offset the imbalances that could benefit some regions in the core of the continent at the expense of regions at its periphery. ${ }^{1}$ In the running financial period 2014-2020, regional policy spending amounts to almost a third of the EU budget (EUR 351.8 billion out of a total EUR 1,082 billion) and is the second largest expenditure item after the Common Agriculture Policy (CAP). Its aim is to reduce regional economic disparities resulting from geographic remoteness, as different levels of prosperity and opportunity may exist both between and within the Member States. In this respect, mutual support through transfers from richer to poorer regions aims to benefit economically and socially deprived regions and close the gap to the EU average. In broader terms, the overall goal is 'economic, social and territorial cohesion', which translates into boosting competitiveness and economic growth, providing people with better services, job opportunities and better quality of life, and connecting regions. EU regional policy is implemented through a range of European Structural and Investment Funds (ESI) in a shared management system, carried out by each Member State in partnership with the European Commission. First, the Commission negotiates and approves the National Strategic Reference Framework (NSRF), setting out the main priorities for spending provided by the EU, and the Operational Programme (OP), establishing specific regions' priorities, objectives, and concrete actions to manage individual projects. Then, managing authorities in each country and/or region select, monitor, and evaluate individual projects submitted by firms, institutions or other entities. The geographical coverage and allocation of transfers are usually based on the level of GDP per capita in PPP compared to the EU average.

In this contribution, we focus on one of the main financial tools of EU regional policy, i.e. the European Regional Development Fund (ERDF). In particular, we restrict our attention to specific sources supporting firms in their innovation strategies and competitiveness. ${ }^{2}$ Resources are allocated to regional operational programmes that have specified thematic priorities. For instance, the ERDF for Business Support has been established to help firms or groups of firms, in particular, SMEs, with services and investments in innovation and sustainable production. Complementary to the latter, the ERDF for Research, Technology and Development (RTD) stimulates research and innovation activities through investments in research centres, promoting technology transfers and cooperation between businesses and the scientific environment. Overall, we argue that the ERDF has a dual role: first, it aims at improving the environment of regions, and second, it is a direct financial income for the recipient firms, potentially used as a source for investment.

The impacts of regional policies are usually evaluated at aggregated levels, by country or by region. There is no consensus regarding the outcome of the Structural Fund Programme, and research still focuses on aggregate statistics. However, the increasing availability of detailed firm-

\footnotetext{
${ }^{1}$ For details on the core-periphery model and its consequences, see the seminal work by Krugman (1991).

${ }^{2}$ One of the priorities of the EU 'cohesion policy' and a key component of the renewed Lisbon Strategy Europe 2020 concern the support to firms (European Commission, 2010). Grants to firms across Member States are mainly used to support private investment to improve private capital stock (European Commission, 2017).
} 
level data allows a more in-depth investigation of the direct and indirect impact of these policies on their immediate beneficiaries, i.e. the firms, in treated and non-treated regions. Firm-level evidence reveals some facts that are unobservable at the aggregate level, e.g. a large heterogeneity in the competitiveness of firms within the same industry. Heterogeneity of firms and varying absorptive capacity of regions can also explain the observed heterogeneity in the regional policy effects.

In our study, we enrich the relevant empirical literature by testing the impact of the 'cohesion policy' and its tools on the performance of about 500,000 EU manufacturing firms, after estimating their total factor productivities (TFPs) according to the most recent semi-parametric econometric technique proposed by Ackerberg et al. (2015). Our purpose is to assess the short-term impact of both the Business Support and the Research, Technology and Development (RTD) financing from ERDF on the firm-level TFP growth in the period 2007-2015. In the Single Market, increasing economic integration is thought to have a positive impact on productivity due to stronger competitive pressure coming from the elimination of national borders. Firms compete on an EU-wide basis, and so we estimate firms' productivity using elasticities computed by industries across the whole sample of EU members. The EU-wide approach allows for a comparison of each firm with its peers within and across the national borders of the integrated market. Finally, we also control for a selection bias possibly coming from uneven missing information in some countries, due to different national regulations for financial accounts. To this end, we make our results robust to a Heckman (1979) correction.

First, we find a positive and statistically significant impact of Research, Technology and Development (RTD) by $\mathrm{ERDF}^{3}$ on productivity growth. In fact, the firms that seem to benefit more from the RTD measure are the ones in the first quartile of the productivity distribution, i.e. the less efficient in a region. By contrast, the Business Support vehicle by ERDF has a negative and statistically significant impact on productivity growth in the short term. Also, in this case, the first quartile of the firms' productivity distribution is where a stronger impact can be detected. On the one hand, our results suggest that the aim of RTD is on average reached, as direct investments in $R \& D$ activities seem to improve firms' overall performance, possibly thanks to developing new products and processes. On the other hand, a general Business Support ${ }^{4}$ funding appears to have unintended consequences, although at this stage we cannot exclude that a positive future impact can still be revealed in the longer run, given the diverse priority themes.

This paper is organised as follows. The next section collects the state of the literature on the

\footnotetext{
${ }^{3}$ The RTD's priority themes for the period 2007-2013, laid down in Commission Regulation (EC) No 1828/2006, were: 01 . R\&TD activities in research centres; 02. R\&TD infrastructure and centres of competence in a specific technology; 03. Technology transfer and improvement of cooperation networks between small and medium-sized businesses (SMEs), between these and other businesses and universities, post-secondary education establishments of all kinds, regional authorities, research centres and scientific and technological poles; 04. Assistance to R\&TD, particularly in SMEs; 07. Investment in firms directly linked to research and innovation; 09. Other measures to stimulate research and innovation and entrepreneurship in SMEs.

${ }^{4}$ The Business Support's priority themes for the period 2007-2013, laid down in Commission Regulation (EC) No 1828/2006, were: 05. Advanced support services for firms and groups of firms; 06. Assistance to SMEs for the promotion of environmentally-friendly products and production processes; 08. Other investment in firms; 63 . Design and dissemination of innovative and more productive ways of organising work.
} 
evaluation of Structural Funds Programme and the total factor productivity estimation. Then, Section 3 provides a thorough description of firm-level data and the TFP sample, which then we combine with regional policy data. Section 4 presents the empirical strategy, and Section 5 discusses the benchmark results and the robustness checks. The last section offers the summary of key findings and concluding remarks.

\section{Related Literature}

A large body of literature evaluates the regional and national effects of the EU regional policies, motivated by the relevant size of the budget and the supranational role of the European Commission in developing the policy agenda. Among others, Boldrin and Canova (2001) find little evidence that regional policies of the EU-15 were effective in terms of promoting economic growth and fast convergence in per capita income during the period until 1997. They conclude that transfers towards poorer regions had mostly a redistribution purpose. On the same line, Dall'Erba and Le Gallo (2008) find no significant effects of structural funds on the convergence of 145 European regions over the period 1989-1999. Ederveen et al. (2003) reveal that poorer regions caught up with richer regions; however, the extent to which this was due to the cohesion policy is ambiguous. They state that cohesion support has a positive impact in lagging member states if their economies are open. Conversely, Cappelen et al. (2003) find a significant and positive impact of EU regional support on the growth of the European regions after the major reform of structural funds in 1988. Nevertheless, their results show that the effect of the funds was stronger in regions with a favourable industrial structure and with an emphasis put on R\&D. Similarly, Leonardi (2006), using sigma- and betaconvergence argues that as a result of the 'cohesion policy' from 1989 on, the gap between core and peripheral areas in the EU shrank. Assessing the impact of the 'cohesion policy' is challenging because it addresses different economic and social objectives. Thus, aggregate analysis can be misleading, in fact, the average effect hides impacts of varying intensity and time span related to the diverse policy fields.

A relatively meagre body of literature assesses the impact of this funding system on firms' outcomes. Bernini and Pellegrini (2011) consider subsidies to Southern Italian regions over the period 1996-2004 and find a positive effect on output, employment and fixed assets in subsidized firms, but slower growth in the TFP than in non-beneficiaries firms. Additionally, Hartsenko and Sauga (2012) positively assess the effectiveness of different types of grants on Estonian firms net sales. While these studies are restricted to specific European regions, De Zwann and Merlevede (2013) propose a EU-wide investigation combining regional data with firm-level data for the period 2000-2006. Their preliminary results show that there is no evidence of average treatment effect on employment and productivity. In this framework, we argue that there is a lack of EU-wide studies of regional policy across the distribution of firm's outcomes.

In the regional economics literature, there are several empirical analysis studying the impact of public subsidies on total factor productivity at the firm level. Bergström (2000) examines the 
effects on TFP of public capital subsidies to manufacturing firms in Sweden between 1987 and 1993. The study shows that subsidisation can impact on growth in the first year the support is granted, but thereafter TFP growth deteriorates. Harris and Trainor (2005) use detailed micro panel data distinguishing firms that receive assistance and those that did not for the manufacturing industry in North Ireland. They find that public subsidies to firms throughout the 1983-1998 period have a positive and significant impact on the level of production, and capital transfers are more likely to affect TFP than other forms of financial support positively.

Further, we also relate to the literature on the firm-level total factor productivity (TFP) dispersion as a measure of heterogeneity. Syverson (2011) surveys recent empirical works, and the common finding is that productivity differences among firms within an industry are large and robust to alternative estimation methods. Using data from the 1977 Census of Manufactures (CM), Syverson (2004b) find that establishments at the $90^{\text {th }}$ percentile of the within 4-digit-SIC productivity distribution are nearly twice as productive as those at the $10^{t h}$ percentile. Also, Syverson (2004a,b) shows that the productivity variation across industries and geographic areas is persistent and it can be related to indicators of product substitutability, market structure, and competition. Hsieh and Klenow (2009) show that under certain assumptions about technology and demand, dispersion in revenue productivity reflects market distortions. In addition, using micro-data on manufacturing, they quantify the potential extent of dispersion as an indicator of misallocation in China and India versus the United States. Recently, Foster et al. (2016) explore the current interpretations of firmlevel dispersion in revenue-based productivity measures. Their empirical evidence suggests, under iso-elastic demand, that dispersion may indicate either distortions or variation in demand shocks and/or technical efficiency.

The kinds of literature that we briefly reviewed above are lacking an appropriate assessment of regional policies of the EU on the performance of firms across the whole Single Market. Therefore, the contribution of this paper is twofold. First, we contribute to the existing literature by estimating the firm-level TFP in a 'continental' approach encompassing 32 countries across the Wider Europe using recent methodological techniques. Second, identifying the location of firms within NUTS-2 regions, we assess the impact of European Regional Development Funds (ERDF) on the growth of firms' TFP during the period 2007-2015. The results of the study may provide insightful information and implications for policy-makers at the EU-level and in general across the advanced economies.

\section{Data}

\subsection{Firm-level data}

In the recent decades, the interconnected and complex global economy has called for an in-depth analysis of micro-agents which from the bottom shape the macro dynamics (Mayer and Ottaviano, 2008). Firm-level data have become a valuable tool for structural analysis and empirical evidence on several issues: assessing and comparing the productivity at different levels of aggregation, investigating innovation and entrepreneurship, understanding the effects of globalisation, moreover, 
linking the financial and employment decisions of firms to aggregate economic outcomes, among others.

Firm-level data are usually sourced from national and/or local public agencies (e.g. business registers, production survey, tax returns), but their public access is often restricted mostly because of the risk of disclosing confidential information. As an alternative, commercial databases gather firm-level information about firms located worldwide, when confidentiality is handled. For the purpose of our analysis, the reliability of firm-level balance sheet data is related to the coverage and the quality of information for each firm. We use the ORBIS database by Bureau Van Dijk (BvDEP), which contains financial and ownership information on millions of mostly private companies around the world, organised in a standard format after integration and harmonisation. ${ }^{5}$

Because of its broad coverage regarding statistical units ${ }^{6}$ and time, and international comparability, it is possible to investigate firm's behaviour by industry, size, country and region over time. Coverage of small firms and balance sheet variables changes from country to country according to the filing requirements by business registers in each country (Kalemli-Ozcan et al., 2015), contributing to measurement errors, classification biases, selection biases, etc.. ${ }^{7}$ Hence, there is a trade-off between coverage (i.e. the number of firms, variables and countries) and the accuracy of the conducted analysis. For instance, the contemporaneous presence of some balance sheet information, namely turnover, material cost, fixed assets and employees, necessary to compute the total factor productivity reduces the available initial sample significantly. ${ }^{8}$

As a starting point, we briefly present the coverage and quality of the sample we end up to compute total factor productivity estimations. Table 1 provides information about European firms operating in manufacturing (sectors 10-33 in second revision Nomenclature générale des activités économiques dans les Communautés européenes, NACE), for which complete data are available over the period 2007-2015. We show the coverage on the population of firms provided by the Structural Business Statistics of Eurostat for each country and NACE rev.2 2-digit sector, as total economy percentages for the year $2013 .^{9}$

\footnotetext{
${ }^{5}$ There is an increasing number of studies from different empirical literatures using ORBIS data. For instance, recent OECD research has used cross-country firm-level data from ORBIS to measure total factor productivity, see Gal (2013).

${ }^{6}$ Some shortcomings may arise when defining the unit of analysis: firms that operate in more than one country have at least one unit counted in each country; only in some countries the business register keeps track of organisational changes (i.e. mergers and acquisitions) within and between firms, and also the definition of legal units may vary across countries.

${ }^{7}$ It is well-known that limited liability companies, although they are required to register their formation, may not report complete balance sheet information in compliance with the national law which differs across countries. Moreover, official business surveys have administrative thresholds (e.g. VAT), below which some businesses are excluded. Therefore, concerns about possible sample selection by country and/or by size must be carefully addressed. Besides, a wider coverage of countries implies the lack of certain variables, i.e. value-added and intermediate inputs which are necessary to measure TFP. Another weakness is the availability of employment information, which is not a mandatory item in balance sheets but rather reported in a memorandum.

${ }^{8}$ Many researchers have experienced a large number of unique firm identifiers, but many missing values for financial values, as reported in Kalemli-Ozcan et al. (2015). It appears that there is a reporting lag of about two years on average, so for instance information about a firm in 2010 may fully appear in 2012.

${ }^{9}$ Structural business statistics (SBS) data is collected using statistical surveys, business registers or from various administrative sources across the European Union (EU). Starting in 1995, the SBS provides information on many key
} 
A noteworthy feature of the data is a high coverage of turnover for some countries, although the percentage of operating firms in the year 2013 is much lower. For instance, for Bulgaria, since the percentage of turnover and labour is very good, but the number of firms is lower than the one reported by Eurostat, we can suggest that ORBIS has information on large firms. For Austria and some other countries, the coverage of labour is lower than the one of turnover; one reason could be that firms in ORBIS are less labour-intensive than the ones in Eurostat. First evidence suggests that for most countries there is an over-representation of medium and large firms in our sample, compared to the majority of small and medium-sized enterprises (SMEs) within the European Union. ${ }^{10}$ The latter is confirmed in Table 2 where the size distribution regarding the number of firms for each country is reported. For countries like Austria, Belgium, Denmark, Netherlands and the United Kingdom, the highest number of firms in ORBIS is of medium size. However, the sample selection on the size is less severe, in terms of representativeness of the sample, when looking at the percentage of firms within each sector. Table 3 shows that there is a good sector coverage for most countries. Some exceptions are less labour-intensive sectors, such as NACE 13-15 and NACE 16-18, which are overall under-represented. ${ }^{11}$

variables, such as turnover, value-added, employment, the number of business units, etc., broken down by industries and size for each country. Notice that changes in the specific purposes (e.g. tax collection, government policies, etc.) of the administrative sources may affect the coverage, definition, thresholds, etc., of the data. The sample coverage for the other years in the study is available upon request.

${ }^{10}$ The over-representation for the largest firms in the ORBIS database is well understood. See Ribeiro et al. (2010) and Kalemli-Ozcan et al. (2015) for more details.

${ }^{11}$ Notice that the primary activity code attributed to each firm may differ in ORBIS and Eurostat. While in the latter the criterion of attributing the activity is based on the initial classification of the firm at the time of its set up, ORBIS classification is based on the current production of the firm, therefore a more accurate information. 
Table 1: Sample coverage, year 2013.

\begin{tabular}{|c|c|c|c|c|c|c|c|c|c|}
\hline \multirow[b]{2}{*}{ Country } & \multicolumn{3}{|c|}{ Turnover } & \multicolumn{3}{|c|}{ N. of employees } & \multicolumn{3}{|c|}{ N. of firms } \\
\hline & Sample & Eurostat & $\%$ & Sample & Eurostat & $\%$ & Sample & Eurostat & $\%$ \\
\hline Austria & 77,724 & 176,744 & 43.98 & 215,039 & 617,441 & 34.83 & 760 & 25,129 & 3.02 \\
\hline Belgium & 224,957 & 267,274 & 84.17 & 297,804 & 514,258 & 57.91 & 2,732 & 33,468 & 8.16 \\
\hline Bosnia-Herz. & 5,661 & 6,635 & 85.33 & 111,217 & 122,089 & 91.10 & 3,784 & 4,440 & 85.23 \\
\hline Bulgaria & 21,742 & 22,566 & 96.35 & 503,980 & 524,041 & 96.17 & 15,607 & 30,091 & 51.87 \\
\hline Croatia & 13,793 & 16,044 & 85.97 & 181,939 & 260,534 & 69.83 & 7,724 & 20,673 & 37.36 \\
\hline Cyprus & 693 & 2,585 & 26.80 & 4,312 & 25,583 & 16.85 & 95 & 4,947 & 1.92 \\
\hline Czech Rep. & 137,125 & 139,840 & 98.06 & 989,866 & $1,160,215$ & 85.32 & 14,702 & 167,688 & 8.77 \\
\hline Denmark & 35,178 & 93,000 & 37.83 & 84,615 & 351,178 & 24.09 & 573 & 15,062 & 3.80 \\
\hline Estonia & 583 & 11,142 & 5.24 & 80,228 & 104,565 & 76.73 & 3,871 & 6,381 & 60.66 \\
\hline Finland & 58,559 & 113,213 & 51.72 & 182,904 & 330,472 & 55.35 & 6,369 & 21,581 & 29.51 \\
\hline France & 471,945 & 870,241 & 54.23 & $1,278,008$ & $2,993,901$ & 42.69 & 27,953 & 226,369 & 12.35 \\
\hline Germany & 689,905 & $1,975,826$ & 34.92 & $1,830,210$ & $7,220,296$ & 25.35 & 13,134 & 202,823 & 6.48 \\
\hline Greece & 23,131 & 56,478 & 40.96 & 134,025 & 289,187 & 46.35 & 4,417 & 57,736 & 7.65 \\
\hline Hungary & 84,421 & 93,802 & 90.00 & 447,036 & 664,724 & 67.25 & 3,003 & 47,475 & 6.33 \\
\hline Italy & 661,432 & 872,479 & 75.81 & $2,384,401$ & $3,733,694$ & 63.86 & 105,399 & 407,344 & 25.87 \\
\hline Latvia & 5,945 & 7,517 & 79.09 & 98,116 & 120,761 & 81.25 & 5,525 & 9,535 & 57.94 \\
\hline Lithuania & 7,301 & 13,508 & 54.05 & 90,917 & 195,701 & 46.46 & 1,286 & 16,120 & 7.98 \\
\hline Luxembourg & 2,480 & 4,161 & 59.58 & 9,137 & 19,008 & 48.07 & 99 & 733 & 13.51 \\
\hline Macedonia & 1,552 & 1,805 & 85.98 & 74,009 & 74,009 & 81.20 & 4,838 & 7,135 & 67.81 \\
\hline Malta & 158 & 383 & 41.25 & 2,351 & 7,786 & 30.20 & 52 & 1,279 & 4.07 \\
\hline Netherlands & 40,741 & 308,574 & 13.20 & 54,109 & 681,617 & 7.94 & 519 & 60,506 & 0.86 \\
\hline Poland & 51,226 & 270,727 & 18.92 & 350,377 & $2,347,504$ & 14.93 & 3,029 & 174,414 & 1.74 \\
\hline Portugal & 73,470 & 79,429 & 92.50 & 536,092 & 637,427 & 84.10 & 26,797 & 66,423 & 40.34 \\
\hline Romania & 61,854 & 65,677 & 94.18 & $1,053,333$ & $1,166,313$ & 90.31 & 30,125 & 46,761 & 64.42 \\
\hline Slovenia & 18,745 & 23,848 & 78.60 & 124,064 & 176,175 & 70.42 & 6,285 & 18,148 & 34.63 \\
\hline Slovakia & 58,357 & 61,104 & 95.50 & 357,157 & 437,796 & 81.58 & 6,863 & 63,185 & 10.86 \\
\hline Spain & 322,576 & 447,415 & 72.10 & $1,115,379$ & $1,736,651$ & 64.23 & 56,018 & 168,935 & 33.16 \\
\hline Sweden & 152,804 & 197,809 & 77.25 & 407,280 & 631,140 & 64.53 & 12,633 & 53,681 & 23.53 \\
\hline UK & 399,185 & 576,651 & 69.22 & $1,278,672$ & $2,368,775$ & 53.98 & 9,524 & 127,943 & 7.44 \\
\hline
\end{tabular}

Notes: This table reports variables aggregated at country-level when information by industry is available in the ORBIS and the Eurostat datasets. Turnover is expressed in millions of euros. Firms with consolidated accounts are excluded when considering coverage on turnover and number of employees. Data on Ireland, Montenegro, and Serbia, is not available in Eurostat database. 
Table 2: Size distribution number of firms in the sample and in Eurostat (\%), year 2013.

\begin{tabular}{|c|c|c|c|c|c|c|c|c|c|c|}
\hline \multirow[b]{2}{*}{ Country } & \multicolumn{5}{|c|}{ TFP sample } & \multicolumn{5}{|c|}{ Eurostat } \\
\hline & $0-9$ & 10-19 & $20-49$ & $50-249$ & $250+$ & $0-9$ & 10-19 & $20-49$ & $50-249$ & $250+$ \\
\hline Austria & 3.3 & 1.4 & 6.8 & 48.1 & 40.3 & 72.1 & 11.6 & 8.7 & 5.7 & 1.9 \\
\hline Belgium & 10.7 & 11.2 & 30.8 & 36.0 & 11.3 & 81.7 & 7.6 & 6.1 & 3.6 & 1.0 \\
\hline Bosnia-Herz. & 60.4 & 15.5 & 12.3 & 9.6 & 2.2 & $\mathrm{n} / \mathrm{a}$ & $\mathrm{n} / \mathrm{a}$ & $\mathrm{n} / \mathrm{a}$ & $\mathrm{n} / \mathrm{a}$ & $\mathrm{n} / \mathrm{a}$ \\
\hline Bulgaria & 50.9 & 18.4 & 17.4 & 11.4 & 1.9 & 74.8 & 9.8 & 8.6 & 5.8 & 1.0 \\
\hline Croatia & 66.0 & 14.4 & 10.2 & 7.5 & 1.8 & 83.7 & 7.6 & 4.8 & 3.1 & 0.8 \\
\hline Cyprus & 17.5 & 12.4 & 39.2 & 25.8 & 5.2 & 90.0 & 5.9 & 2.7 & 1.2 & 0.1 \\
\hline Czech Rep. & 41.0 & 17.0 & 18.4 & 18.1 & 5.5 & 92.7 & 2.7 & 2.3 & 1.8 & 0.5 \\
\hline Denmark & 7.5 & 4.7 & 10.8 & 43.1 & 33.9 & 71.2 & 12.4 & 9.0 & 6.2 & 1.2 \\
\hline Estonia & 65.9 & 13.0 & 11.8 & 8.1 & 1.1 & 74.7 & 9.3 & 8.7 & 6.4 & 0.9 \\
\hline Finland & 55.0 & 15.9 & 14.4 & 11.0 & 3.7 & 83.8 & 6.5 & 5.3 & 3.5 & 0.9 \\
\hline France & 58.6 & 14.4 & 13.5 & 10.1 & 3.4 & 86.8 & 5.6 & 4.4 & 2.6 & 0.7 \\
\hline Germany & 13.3 & 13.5 & 20.3 & 34.8 & 18.0 & 61.4 & 20.4 & 8.1 & 8.1 & 2.1 \\
\hline Greece & 35.0 & 25.4 & 23.7 & 12.9 & 3.0 & 95.1 & 2.0 & 1.6 & 1.0 & 0.2 \\
\hline Hungary & 17.8 & 8.6 & 19.9 & 40.2 & 13.5 & 84.5 & 6.5 & 4.8 & 3.4 & 0.8 \\
\hline Ireland & 17.8 & 7.9 & 17.5 & 36.7 & 20.0 & $\mathrm{n} / \mathrm{a}$ & $\mathrm{n} / \mathrm{a}$ & $\mathrm{n} / \mathrm{a}$ & $\mathrm{n} / \mathrm{a}$ & $\mathrm{n} / \mathrm{a}$ \\
\hline Italy & 52.2 & 23.8 & 15.4 & 7.3 & 1.4 & 83.0 & 9.9 & 4.8 & 2.1 & 0.3 \\
\hline Latvia & 66.4 & 13.3 & 11.3 & 8.0 & 1.0 & 79.9 & 8.0 & 6.6 & 4.9 & 0.6 \\
\hline Lithuania & 12.4 & 16.5 & 28.2 & 34.4 & 8.5 & 82.1 & 7.0 & 5.9 & 4.3 & 0.8 \\
\hline Luxembourg & 3.0 & 3.0 & 11.0 & 43.0 & 40.0 & 62.6 & 12.2 & 12.6 & 9.7 & 3.0 \\
\hline Macedonia & 72.2 & 11.6 & 8.7 & 6.6 & 1.0 & $\mathrm{n} / \mathrm{a}$ & $\mathrm{n} / \mathrm{a}$ & $\mathrm{n} / \mathrm{a}$ & $\mathrm{n} / \mathrm{a}$ & $\mathrm{n} / \mathrm{a}$ \\
\hline Malta & 14.8 & 6.6 & 19.7 & 42.6 & 16.4 & 91.1 & 6.2 & 0.0 & 2.7 & 0.0 \\
\hline Montenegro & 67.4 & 14.7 & 10.5 & 5.3 & 2.1 & $\mathrm{n} / \mathrm{a}$ & $\mathrm{n} / \mathrm{a}$ & $\mathrm{n} / \mathrm{a}$ & $\mathrm{n} / \mathrm{a}$ & $\mathrm{n} / \mathrm{a}$ \\
\hline Netherlands & 7.1 & 3.5 & 11.4 & 48.7 & 29.3 & 85.8 & 5.8 & 4.5 & 3.3 & 0.6 \\
\hline Poland & 28.4 & 2.3 & 27.2 & 29.1 & 12.9 & 86.9 & 4.6 & 4.2 & 3.5 & 0.9 \\
\hline Portugal & 61.3 & 18.0 & 13.0 & 6.8 & 0.9 & 82.6 & 8.2 & 5.8 & 3.0 & 0.4 \\
\hline Romania & 58.8 & 15.4 & 13.9 & 9.5 & 2.3 & 70.6 & 11.4 & 9.7 & 6.7 & 1.6 \\
\hline Serbia & 65.1 & 14.7 & 10.4 & 7.8 & 2.0 & $\mathrm{n} / \mathrm{a}$ & $\mathrm{n} / \mathrm{a}$ & $\mathrm{n} / \mathrm{a}$ & $\mathrm{n} / \mathrm{a}$ & $\mathrm{n} / \mathrm{a}$ \\
\hline Slovenia & 74.7 & 10.5 & 7.1 & 6.1 & 1.5 & 88.5 & 5.0 & 3.2 & 2.7 & 0.6 \\
\hline Slovakia & 52.2 & 16.8 & 14.2 & 12.9 & 3.8 & 94.0 & 2.2 & 1.8 & 1.5 & 0.4 \\
\hline Spain & 63.7 & 16.8 & 12.4 & 5.8 & 1.2 & 83.6 & 8.1 & 5.5 & 2.4 & 0.4 \\
\hline Sweden & 57.3 & 18.1 & 13.3 & 8.7 & 2.7 & 87.8 & 5.3 & 3.9 & 2.4 & 0.6 \\
\hline UK & 4.9 & 4.7 & 15.4 & 57.7 & 17.3 & 76.4 & 10.3 & 7.4 & 4.9 & 1.1 \\
\hline
\end{tabular}

Notes: This table presents the distribution of firms according to their size in the TFP sample and as reported in Eurostat database. It shows the percentages computed on the total number of firms in each country. Each row sums up to $100 \%$ for the two samples. Data on size distribution of firms about Bosnia and Herzegovina, Ireland, Montenegro, Macedonia, and Serbia, is not available in Eurostat database. 


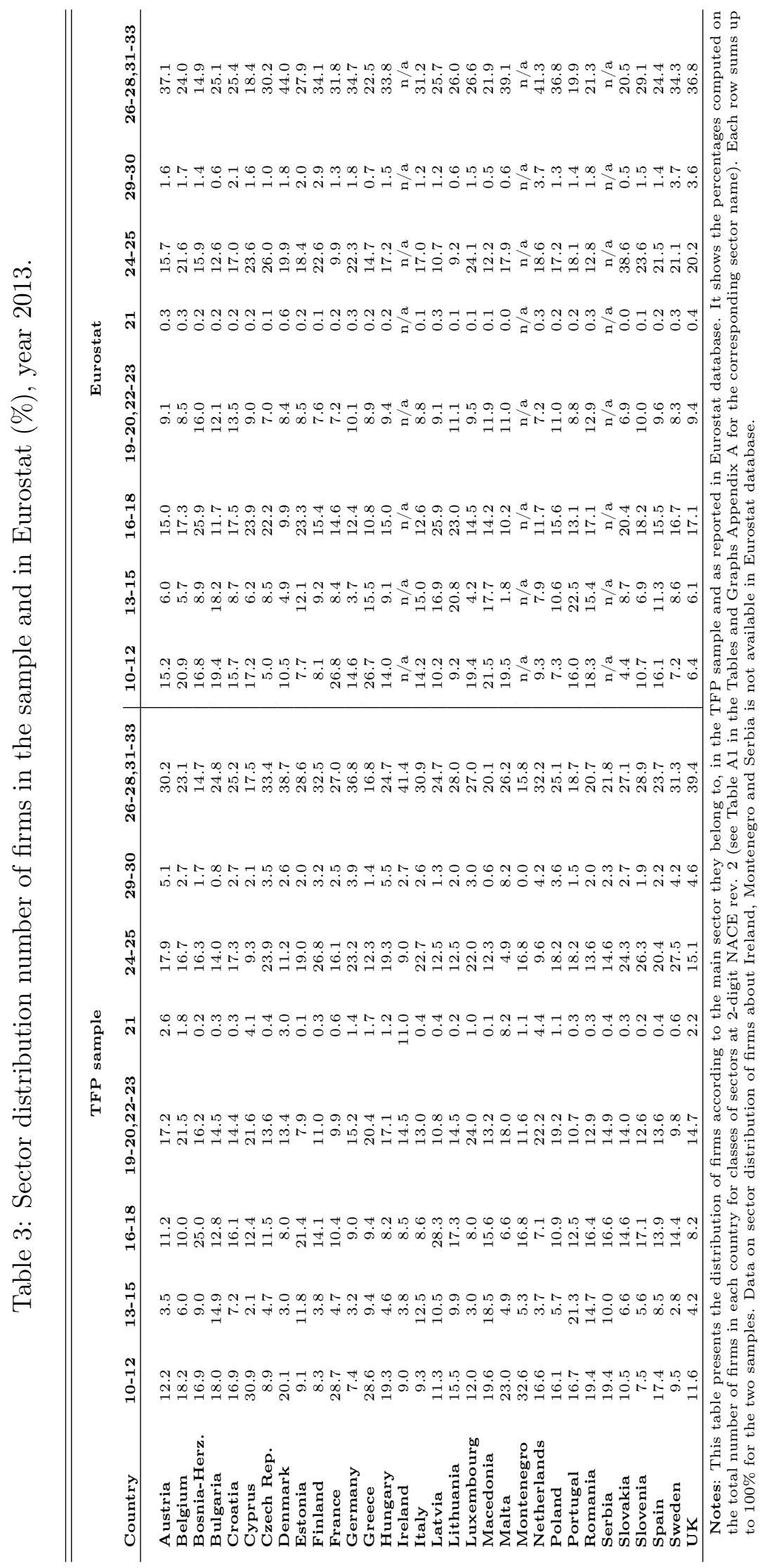




\subsection{Total factor productivity estimation}

\subsubsection{Deflation and international comparability}

To analyse and compare the TFP estimations over time, across countries and industries, we deflate nominal values of variables necessary for the computation and hence report all values in a common real currency-year. First, we convert variables in ORBIS from euros to local currencies at the end of the year for countries outside the Eurozone in each period. ${ }^{12}$ Then, following Smarzynska Javorcik (2004), we separately deflate output, intermediate inputs, and capital using 2-digit industry producer price index (PPI) for each country-year, with the base year 2010. In particular, the output which refers to turnover is deflated using the total PPI of the focal industry from Eurostat and World Bank (WDI). Capital, that is defined as the value of fixed assets at the beginning of the year, is deflated by the simple average of the deflators for the following 2-digit NACE rev. 2 industries: 26, Manufacture of computer, electronic and optical products; 27, Manufacture of electrical equipment; 28, Manufacture of machinery and equipment n.e.c.; 29, Manufacture of motor vehicles, trailers and semi-trailers; 30, Manufacture of other transport equipment.

Intermediate inputs, corresponding to material costs, are deflated by the intermediate inputs' deflator that is calculated as the weighted average of PPI of the supplying industries, with technical coefficients (expenditure shares of input industries) as weights retrieved from the WIOD inputoutput tables (2016 Release). ${ }^{13}$ In fact, these weights are representing the proportion of inputs sourced from a given sector.

We deal with missing PPI in several ways, after checking the availability in National Statistic Office tables: if the data are missing for the whole industry, we use the more aggregated PPI on manufacturing; if the data is missing for one or more years, we interpolate using the closest years; if it is not possible to construct the deflator for material cost, we use the aggregate PPI on intermediate goods; also, some adjustments for specific industries' aggregations are done to correspond to WIOD industry groups (e.g. we use NACE 31-32 in WIOD for the aggregation 31-33 in PPI).

Finally, we convert back the deflated variables in the domestic currency to euro, using the relevant exchange rate of the (base) year 2010. This procedure ensures that the change in prices does not distort the level and the growth of TFP.

\subsubsection{The 'continental' approach and preliminary evidence}

Exploiting the unique dataset of 567,405 manufacturing firms from 32 European countries, including the EU28 plus the Western Balkans, for the period 2007-2015, we estimate firm-level total factor productivities applying the most recent econometric techniques. ${ }^{14}$ For each firm $i$ in industry $j$ (at

\footnotetext{
${ }^{12}$ The values of the variables in ORBIS are expressed in euro currency at market exchange rate, at the end of the corresponding year.

${ }^{13}$ The extended World Input-Output Database (WIOD) covers 28 EU countries and 15 other major countries in the world for the period 2000-2014. All the details are offered in Timmer et al. (2016). For the year 2015, which is part of our study, we use the weights of 2014.

${ }^{14}$ There is a general consensus on the broad definition of TFP which considers TFP as the efficiency of a firm to turn inputs of production such as capital, labour, and intermediate inputs into products (Hulten, 2001; Katayama
} 
2-digit NACE rev.2) located in country $c$ at time $t$, we estimate TFP by industry $j$ across the whole sample. While there is an ongoing debate about the most appropriate estimating approach of TFP, we rely on firm-level productivities computed using the production function elasticities estimated with the semi-parametric technique proposed by Ackerberg et al. (2015) (ACF hereafter). ${ }^{15}$

We calculate factor elasticities for each industry on a 'continental' (Wider Europe) scale to assess the competitiveness of firms horizontally across national borders. In the integrated framework of a Single Market, characterised by increasing economic integration, competitive pressure is usually thought to have a diverse impact on productivity as it is referred in the literature of economic geography (Beaudry and Schiffauerova, 2009). For instance, for the Italian firm "PARMALAT s.p.a." the 2013 productivity computed using elasticities at the country-industry level is quite close to the mean of its industry, while using 'continental' estimations it is among the top productive firms within industry NACE 10. This indicates that the Italian manufacturers of food with very high productivity are in general more competitive than other manufacturers in the Wider Europe.

On the contrary, the English firm "LUSH LTD.", operating in industry NACE 20, in 2013 is more productive than the average of its peers using country-industry level elasticities, while using 'continental'-industry elasticities it is below the European average. This suggests that while this firm is a very competitive producer of chemicals within England, it is not very highly productive in the Wider Europe beside other competitors in the industry. In this context, empirical evidence suggests that looking at firms across all countries provides more insightful information on the position of a country industry's competitiveness (Altomonte et al., 2010), especially within a Single Market such as the EU.

Table 4 reports the descriptive statistics of the firm-level TFP in logarithm estimated using the ACF method. The most remarkable feature is the overall dispersion of productivity, measured by the inter-quartile range (IQR), in line with the empirical literature reviewed by Bartelsman and Doms (2000) and Syverson (2011).

Figure 1 shows the percentiles of the firm-level log TFP by country. Heterogeneity in firm performance is widely spread across countries in the sample, and it is linked to some extent to the

et al., 2009; Van Beveren, 2012). According to this literature, the productivity of an individual firm is measured relative to the average ability of all comparable firms within the industry (and/or within a region). The benchmark efficiency and technological level across firms are therefore corrected using econometric techniques.

As for the first time noted in Marschak and Andrews (1944) when a firm chooses the number of inputs according to its productivity, not observable by the econometrician, OLS estimation introduces a simultaneity bias. Furthermore, a selection bias emerges in case a firm decides to enter or exit the market according to its observed level of productivity (Olley and Pakes, 1996). More recently, other important issues emerge from empirical applications. Klette and Griliches (1996) demonstrate how price-induced measurement error can bias the production function estimates, generating an omitted price bias. Eventually, Collard-Wexler and De Loecker (2016) face the measurement error in the capital coefficient, arising from severe errors in recording producer's capital stock.

${ }^{15} \mathrm{ACF}$ argue that the optimal labour allocation is also a deterministic function of TFP and therefore the elasticity of labour is not identified using the semi-parametric estimator of Olley and Pakes (1996). A solution is the identification of the labour coefficient in a second stage, assuming a conditional intermediate inputs demand function. Also, Wooldridge (2009) propose an advantageous approach to circumvent the identification problem by estimating all the coefficients in a single GMM step and using earlier outcomes of both capital and variable inputs as instrumental variables. However, although the latter is robust to the ACF critique and more efficient with respect to a two-step estimation, in our sample, the short time span lead us to implement the ACF method. 
Table 4: Descriptive statistics of TFP (in log) distribution using ACF, 2007-2015.

\begin{tabular}{lccccc}
\hline \hline & Mean & Median & sd & IQR & Observations \\
\hline Ackerberg-Caves-Franzer & 0.91 & 2.99 & 6.73 & 4.40 & $3,010,154$
\end{tabular}

heterogeneity in the size of firms observed within industries (Bartelsman et al., 2013). Nevertheless, there are some empirical regularities. For instance, the median value of productivity is quite similar across countries, and the distance between the $25^{\text {th }}$ and the $10^{t h}$ percentile is in most cases high, meaning that there are few firms in each country with productivity close to zero which is in line with the under-representation of micro firms in our sample. On the other hand, if we look at the $90^{\text {th }}$ percentile only Denmark and Netherlands exhibit high firm-level productivity.

Figure 1: Percentiles (log) TFP - ACF by country

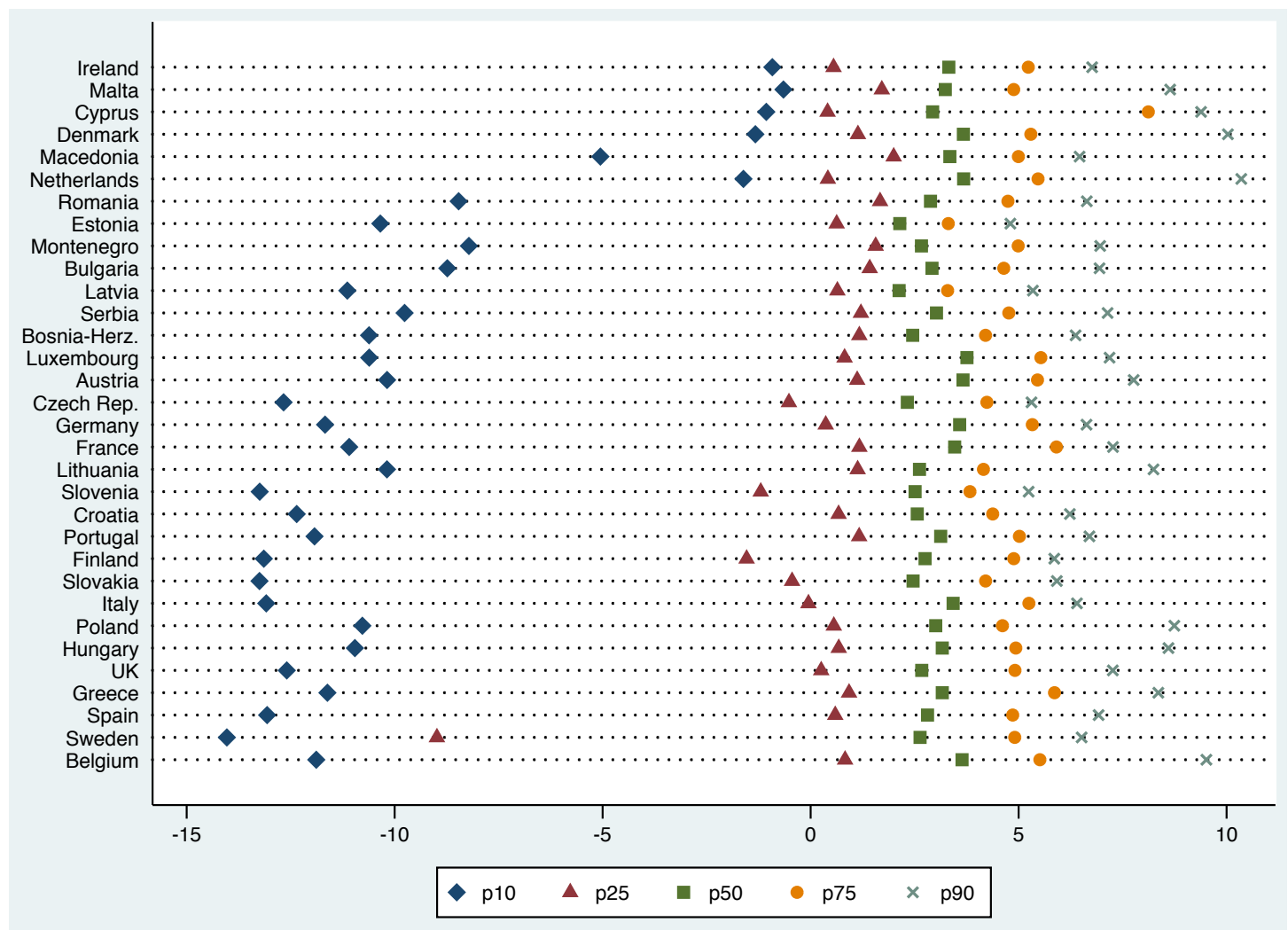

Notes: This Figure shows the firm-level total factor productivity percentiles for each country in the sample. Countries are presented in ascending order according to the difference between the $90^{t h}$ and the $10^{t h}$ percentile.

Source: Own elaboration.

Firms are heterogeneous along many dimensions and their distributions have power-law right tails. Our case is slightly more sophisticated. Take the case of Figure 2, where we compare an assumed normal (Gaussian) distribution with the same average of the actual distribution that we find for the TFP of EU firms. At first glance, we observe an asymmetric bimodal distribution. In other words, there are two different sets of firms. On the left side of the actual TFP distribution, there 
Figure 2: Total factor productivity distribution of EU manufacturing firms.

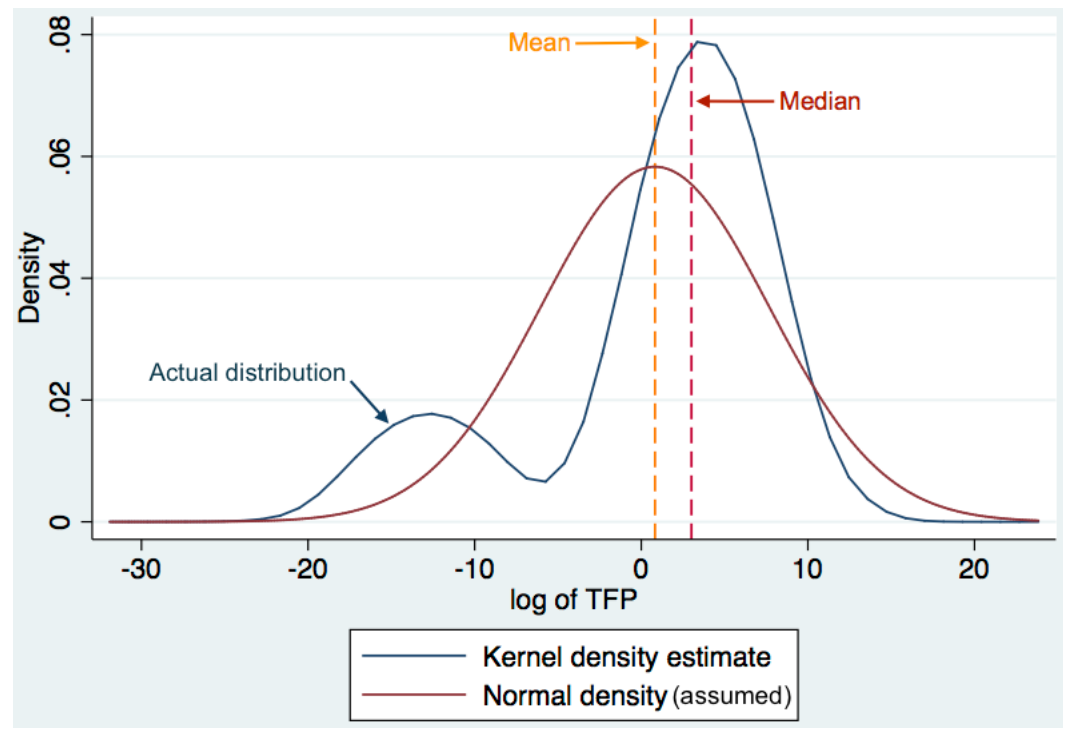

Source: Own elaboration.

is a bunch of firms significantly less productive than the ones on the right side of the distribution, yet active on the market and far from going bankrupt, like in a world apart. Such a polarisation in productivity on a 'continental' level is unexplained, and its origin is not the object of study of the present contribution. In the context of our exercise, we note that the average effect of ERDF financial support on firms' productivity growth could deliver a distorted picture of what really happens on the field.

To better understand firm-level dynamics, Figure A.1 in Tables and Graphs Appendix A compares the firm-level distributions of TFP at the beginning and the end of the period under investigation. For most countries, the distribution remains unchanged between the two years with the overall tendency towards a high concentration of low productivity firms. Eventually, the shape of the TFP distribution differs across countries, reflecting their structural characteristics.

\subsection{Regional policy data}

We retrieve data on regional policy funding from the report 'Geography of Expenditure - Work Package 13' prepared for the European Commission in 2015 (wiiw and ISMERI EUROPA, 2015). The report studies the cumulative allocations to selected projects and the expenditures of European Regional Development Funds (ERDF) and Cohesion Fund (CF) over the programming period 2007-2013 for all 28 EU countries. Most of the transfers are assigned at the NUTS-2 level. ${ }^{16}$ Overall, the Structural funds Programme distinguishes transfers by objectives: Convergence (Objective

\footnotetext{
${ }^{16}$ NUTS is the acronym for Nomenclature des Unités Territoriales Statistiques and it is a hierarchical system to for dividing the economic territory of the EU. The highest level of aggregation (NUTS-1) corresponds to major socioeconomic regions (e.g. the United Kingdom's regions of England/Scotland/Wales); NUTS-2 refers to basic regions for the application of regional policies (e.g. Italian regions); and NUTS-3 identifies small regions for specific diagnosis (e.g. Départements in France).
} 
1), Regional competitiveness and employment (Objective 2), and European territorial cooperation (Objective 3). We restrict our analysis to the Objective 1 which aims at accelerating the economic development of lagging EU regions and it accounts for more than two-thirds of the programme's total budget. The objective covers regions whose GDP per capita in PPP is less than $75 \%$ of the EU average. In this work, we focus on the ERDF established in 1975, in particular on two thematic areas which may have a direct impact on firm's productivity: Business Support, and Research, Technology and Development (RTD).

Figure 3 provides insights on the distribution of payments across NUTS-2 regions for the two priorities mentioned above. The total value of projects subsidised over the whole programming period 2007-2013 by the ERDF Business Support summed up to roughly EUR 21 billion, compared to EUR 35 billion from the ERDF RTD. In a regional approach, the amount of transfers for Business Support varied from EUR 53,987 in Schwaben (Germany) to over EUR 842 million in Andalusia (Spain), with an average of about EUR 82 million per region. Financial aid for research, technology and development ranges from EUR 295,576 in South East England to more than EUR 1.5 billion in the Warsaw region (Poland). On average, every region received EUR 132 million for projects involved in innovation and development activity. In the populous and usually rich regions such as those in England, Belgium, the Netherlands, parts of Germany, Austria and Northern Italy, ERDF payments usually do not exceed $0.1 \%$ of the regional GDP over the entire period of financing. The regions with the highest ERDF payments as a share of regional GDP are Észak-Magyarország in Hungary with $0.54 \%$ (ERDF Business Support) and Alentejo in Portugal with $0.47 \%$ (ERDF RTD), respectively.

We combine the regional policy data on ERDF with the firm-level data for which we are able to estimate total factor productivity and to identify a firm's location by postal codes and then corresponding it to NUTS-2 regions using concordance tables from Eurostat. ${ }^{17}$ It is important to note that while the programme's commitment is in the period 2007-2013, the allocation of funds usually takes 1-2 years longer ending in 2015 for some regions. Moreover, there are some overlaps of the allocated funds from the previous programme in the period 2000-2006. However, there are some disparities in the priorities of the two programs. Here we mainly focus on the allocated funds in the program 2007-2013, while the results of the analysis are consistent even after including the total overlapped funds of the two programs, the results of which are available upon request.

\footnotetext{
${ }^{17}$ http://ec.europa.eu/eurostat/tercet/flatfiles.do
} 
Figure 3: Payments by NUTS-2 region from the European Regional Development Fund.

Total ERDF for Business Support

Programming period 2007-2013

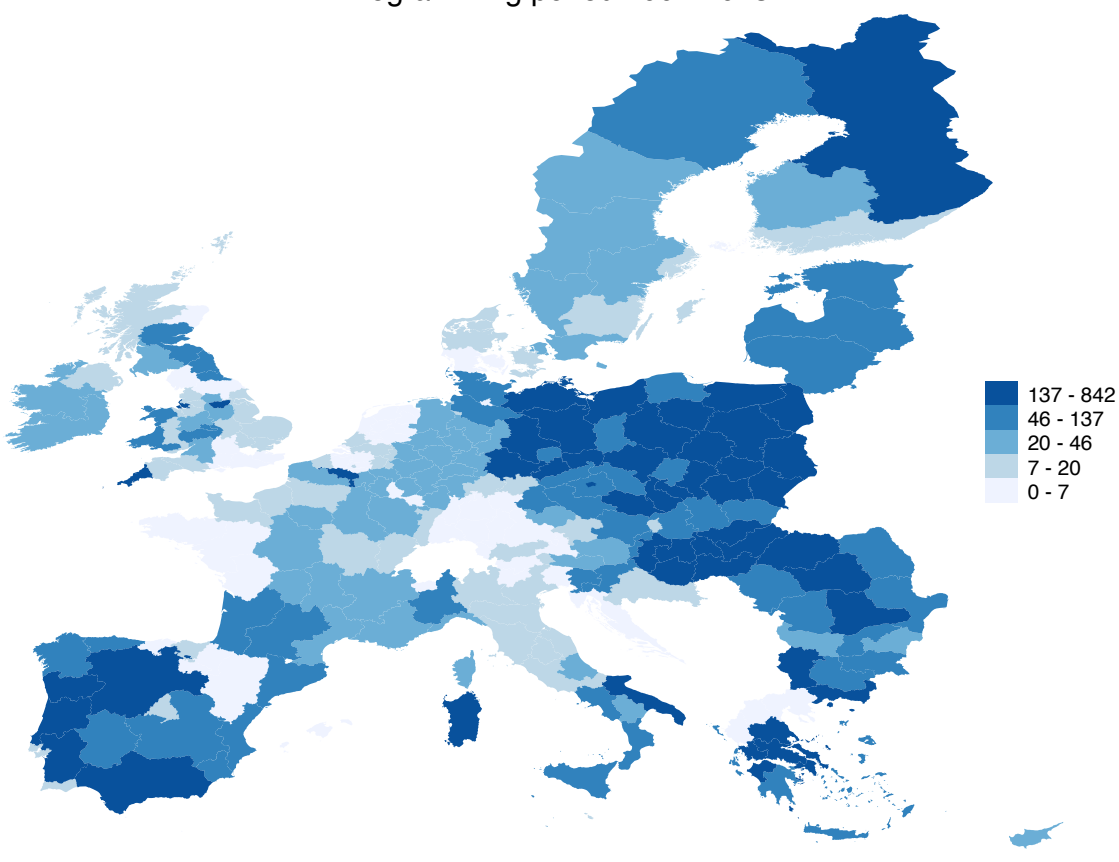

Total ERDF for Research, Technology and Development

Programming period 2007-2013

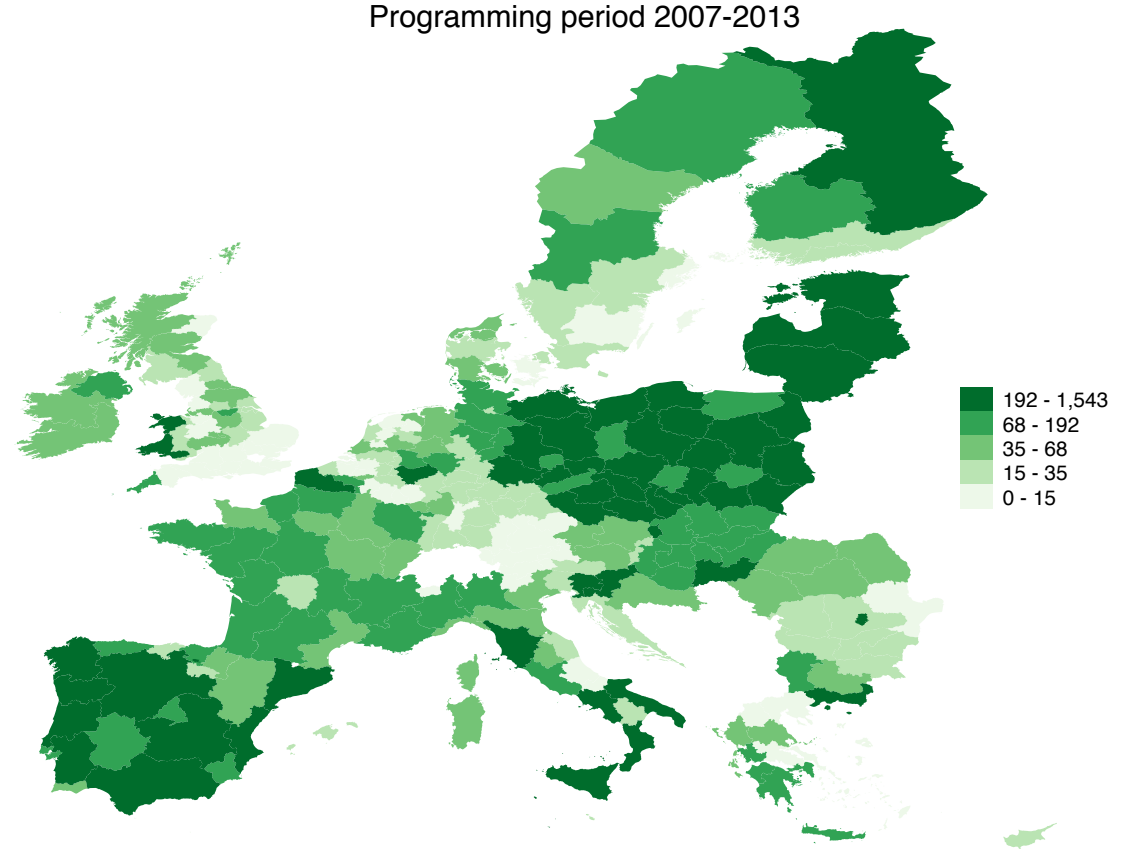

Note: Values in EUR million.

Source: 'Geography of Expenditure - Final Report, Work Package 13', wiiw and ISMERI EUROPA, 2015, own elaboration. 


\section{Empirical strategy}

Our contribution aims at investigating the short-term impact of regional policy spendings on the firm-level TFP growth for the 28 EU member states for the period 2007-2015. We make our results robust to the Heckman $(1976,1979)$ correction accounting for the sample selection on size in our sample. ${ }^{18}$ We use maximum likelihood estimation using the following equations.

The outcome equation is:

$$
\Delta\left(t f p_{i j r t}\right)=\beta_{0}+\beta_{1} t f p_{i j r, t-1}+X_{i j r t} \boldsymbol{\beta}+Z_{j r t} \boldsymbol{\beta}+R_{r t} \boldsymbol{\beta}+\delta_{t}+\mu_{i j r t}
$$

where the dependent variable $\Delta\left(t f p_{i j r t}\right)$ is the growth of total factor productivity ${ }^{19}$, in logarithm, of firm $i$ operating in industry $j$ located in region $r$ at time $t$. On the other side of the equation, we include the TFP level at time $t-1$, testing for the absolute conditional convergence and the main variables of interest contained in $R_{r t}$, i.e. the ERDF fund of categories Business Support and RTD. Then, we refine this specification adding some control variables at firm, industry and regional level. In particular, at the firm-level, in $X_{i j r t}$ we include the number of employees and the size based on turnover. Among the industrial covariates grouped in $Z_{j r t}$, we also test the impact of agglomeration, specialization, diversification and competition externalities. ${ }^{20}$ Whereas, regional GDP and the percentage of the regional population aged between 25 and 64 in education levels 3-4 and 5-8, contained in $R_{r t}$, capture regional peculiarities that may affect the TFP growth. Moreover, we include time dummies and we cluster by region.

The dependent variable $\Delta\left(t f p_{i j r t}\right)$, however, is not always observed. Missing information on one of the variables needed for the estimation of TFP leads to the exclusion of some firms from the final analysis. Therefore, we use a selection equation to estimate whether a firm is included in the sample for which TFP was computed. The selection equation is the following:

$$
Y_{i j r t}=\beta_{0}+W_{i j r t} \boldsymbol{\beta}+\varepsilon_{i j r t}
$$

where we assume that

$$
\begin{array}{r}
\mu_{i j r t} \sim N(0, \sigma) \\
\varepsilon_{i j r t} \sim N(0,1) \\
\operatorname{corr}\left(\mu_{i j r t}, \varepsilon_{i j r t}\right)=\rho
\end{array}
$$

\footnotetext{
${ }^{18}$ For instance, young firms might not be experienced enough to afford the publication of their complete financial statements. Due to high economies of scale at the firm-level relative to plant-level, multinational enterprises (MNE) might have incentives to produce and offer detailed financial accounting in the headquarters instead of their subsidiaries, reducing the probability of detailed financial statements at the subsidiaries. Legislation on providing complete statements to the designated authorities could be very diverse across countries with different business legal environments. Aforementioned could also lead to the heterogeneity in firm's size for reporting. This heterogeneity could be even more diverse across industries and years.

${ }^{19}$ We use total factor productivities computed following the semi-parametric techniques proposed by Ackerberg et al. (2015).

${ }^{20}$ Based on the economic geography literature, knowledge spillovers can impact upon productivity when economic agents are located nearby from each other. For the details about the construction of these measures of externality see the Data Appendix B.
} 
We denote whether or not we observe the value of the depend variable $\Delta\left(t f p_{i j r t}\right)$ in the outcome equation (1) by a binary variable, i.e., $Y_{i j r t}$. In fact, the observation of the dependent variable $\Delta\left(t f p_{i j r t}\right)$, when $Y_{i j r t}=1$, is a function of the value of the selection equation in (2), which relates a latent variable $Y_{i j r t}$ to some observed characteristics $W_{i j r t}$. The latter is a set of time varying firm variables including: $a g e_{i j r c t}$, a variable computed as the observation year (2015) minus the registered

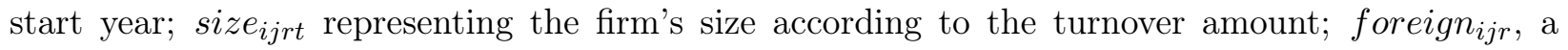
dummy variable which distinguishes domestic from foreign firms; and $\varepsilon_{i j r t}$, the error term.

\section{Results}

Table 5 reports the benchmark results. Overall, we confirm the presence of sample selection in our sample. In particular, results show that the firm's age positively affects the probability of being in the TFP sample. Moreover, we find evidence of conditional absolute convergence in productivity across our population of firms. In other words, the statistically significant negative coefficient of the lag of firm's TFP (in logarithm) would indicate that a representative firm with $1 \%$ lower TFP in the previous period should have about $0.01 \%$ higher TFP growth in the current period.

Then, the Business Support category lagged by one period have a negative and significant (at the $1 \%$ level) short-term effect on productivity growth. Interestingly, after introducing regional variables, the coefficient of Business Support by ERDF becomes negative. A possible explanation is that the positive impact is through regional developments rather than direct impact on the firm. Moreover, looking at the priority themes of this funding, it may be the case that EU investments enhance environmental quality stimulating sustainable production which does not necessarily boost firm's sales or TFP. As mentioned earlier, this result is robust using the previous allocation of this priority in the estimation. Conversely, we find a positive and significant coefficient of RTD by ERDF, at the $10 \%$ level in the current period and at the $5 \%$ for one year lag. In fact, firms receive payments throughout the year, so their effects on firms' performance may become clear in the forthcoming years.

Firm size proxied by the turnover correlates negatively with productivity. On the contrary, the coefficient of the number of employees suggests that the growth of TFP is higher for larger firms. In fact, a $1 \%$ increase in the employment of the firm leads to about $0.02 \%$ higher growth of the TFP. Moreover, we note that the growth of productivity in richer regions as per their GDP is higher. Other regional characteristics, such as the percentage of people aged 25-64 with education levels 3-4 and 5-8 are not significant.

Besides, the coefficient of Agglomeration is negative and significant at 5\%, meaning that the higher is the geographical concentration of an industry in terms of total employment, the lower is the growth of the firm productivity in that regional industry. This attains similar results to the seminal work by Glaeser et al. (1992) over the US cities and the study by De Lucio et al. (2002) over the Spanish regions that agglomeration hinders the growth of regional industries.

We explore the robustness of the main findings across the percentiles of the distribution of TFP. 
Table 5: Heckman selection model for TFP.

\begin{tabular}{|c|c|c|c|c|c|c|c|}
\hline Dep. Var.: $\Delta\left(t f p_{i j r t}\right)$ & $(1)$ & 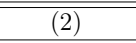 & (3) & $(4)$ & 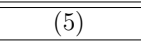 & 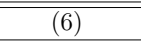 & (7) \\
\hline$t f p_{i j r t, t-1}$ & $\begin{array}{c}-0.0092^{* * *} \\
(0.00074)\end{array}$ & $\begin{array}{c}-0.0091 * * * \\
(0.00074)\end{array}$ & $\begin{array}{c}-0.0092^{* * *} \\
(0.00074)\end{array}$ & $\begin{array}{c}-0.0092^{* * *} \\
(0.00074)\end{array}$ & $\begin{array}{c}-0.010^{* * *} \\
(0.0010)\end{array}$ & $\begin{array}{c}-0.010^{* * *} \\
(0.0010)\end{array}$ & $\begin{array}{c}-0.0092^{* * *} \\
(0.0010)\end{array}$ \\
\hline ERDF Business support & $\begin{array}{c}0.00093^{* * *} \\
(0.00034)\end{array}$ & $\begin{array}{l}0.00069^{*} \\
(0.00038)\end{array}$ & $\begin{array}{l}-0.000087 \\
(0.00030)\end{array}$ & $\begin{array}{c}-0.000074 \\
(0.00029)\end{array}$ & $\begin{array}{c}-0.0015^{* * *} \\
(0.00050)\end{array}$ & & \\
\hline ERDF Business support ${ }_{t-1}$ & & & & & & $\begin{array}{c}-0.0017^{* * *} \\
(0.00051)\end{array}$ & \\
\hline ERDF Business support $_{t-2}$ & & & & & & & $\begin{array}{c}-0.0016 \\
(0.00099)\end{array}$ \\
\hline ERDF $R T D$ & $\begin{array}{l}-0.00066 \\
(0.00055)\end{array}$ & $\begin{array}{c}0.00013 \\
(0.00063)\end{array}$ & $\begin{array}{c}0.00072 \\
(0.00055)\end{array}$ & $\begin{array}{c}0.00046 \\
(0.00056)\end{array}$ & $\begin{array}{c}0.0012^{*} \\
(0.00069)\end{array}$ & & \\
\hline ERDF $R T D_{t-1}$ & & & & & & $\begin{array}{l}0.0017^{* *} \\
(0.00068)\end{array}$ & \\
\hline ERDF $R T D_{t-2}$ & & & & & & & $\begin{array}{c}0.0014 \\
(0.0011)\end{array}$ \\
\hline Firm size & $\begin{array}{c}0.0041^{* * *} \\
(0.00062)\end{array}$ & $\begin{array}{c}0.0041^{* * *} \\
(0.00061)\end{array}$ & $\begin{array}{c}-0.0069^{* * * *} \\
(0.0019)\end{array}$ & $\begin{array}{c}-0.0073^{* * *} \\
(0.0020)\end{array}$ & $\begin{array}{c}-0.0071^{* * *} \\
(0.0021)\end{array}$ & $\begin{array}{c}-0.0070^{* * *} \\
(0.0021)\end{array}$ & $\begin{array}{c}-0.0050^{* *} \\
(0.0022)\end{array}$ \\
\hline N. of employees & & & $\begin{array}{c}0.017^{* * *} \\
(0.0023)\end{array}$ & $\begin{array}{c}0.018^{* * *} \\
(0.0024)\end{array}$ & $\begin{array}{c}0.020^{* * *} \\
(0.0023)\end{array}$ & $\begin{array}{c}0.020^{* * *} \\
(0.0023)\end{array}$ & $\begin{array}{c}0.019^{* * *} \\
(0.0024)\end{array}$ \\
\hline Regional gdp in millions Euro & & & & $\begin{array}{l}0.00037 \\
(0.0014)\end{array}$ & $\begin{array}{c}0.0053^{* * *} \\
(0.0018)\end{array}$ & $\begin{array}{c}0.0050^{* * *} \\
(0.0018)\end{array}$ & $\begin{array}{l}0.0039^{*} \\
(0.0020)\end{array}$ \\
\hline \% Aged 25-64 (Education levels 3-4) & & & & $\begin{array}{l}-0.00021^{* *} \\
(0.000090)\end{array}$ & $\begin{array}{l}-0.00029^{*} \\
(0.00016)\end{array}$ & $\begin{array}{c}-0.00027^{*} \\
(0.00016)\end{array}$ & $\begin{array}{r}-0.00033^{*} \\
(0.00019)\end{array}$ \\
\hline \% Aged 25-64 (Education levels 5-8) & & & & $\begin{array}{c}-0.000074 \\
(0.00014)\end{array}$ & $\begin{array}{c}0.00012 \\
(0.00019)\end{array}$ & $\begin{array}{c}0.00014 \\
(0.00019)\end{array}$ & $\begin{array}{c}0.00014 \\
(0.00020)\end{array}$ \\
\hline Agglomeration & & & & & $\begin{array}{c}-0.0039^{* *} \\
(0.0016)\end{array}$ & $\begin{array}{c}-0.0038^{* *} \\
(0.0016)\end{array}$ & $\begin{array}{c}-0.0035^{* *} \\
(0.0016)\end{array}$ \\
\hline Specialization & & & & & $\begin{array}{l}-0.013 \\
(0.071)\end{array}$ & $\begin{array}{l}-0.013 \\
(0.071)\end{array}$ & $\begin{array}{l}-0.073 \\
(0.065)\end{array}$ \\
\hline Diversification & & & & & $\begin{array}{l}-0.11 \\
(0.098)\end{array}$ & $\begin{array}{l}-0.11 \\
(0.096)\end{array}$ & $\begin{array}{l}-0.12 \\
(0.13)\end{array}$ \\
\hline Competition & & & & & $\begin{array}{l}-0.035 \\
(0.023)\end{array}$ & $\begin{array}{l}-0.034 \\
(0.023)\end{array}$ & $\begin{array}{l}-0.018 \\
(0.021)\end{array}$ \\
\hline Constant & $\begin{array}{c}-0.049^{* * *} \\
(0.011)\end{array}$ & $\begin{array}{c}-0.044^{* * *} \\
(0.012)\end{array}$ & $\begin{array}{c}0.067^{* * *} \\
(0.026)\end{array}$ & $\begin{array}{c}0.080^{* * *} \\
(0.022)\end{array}$ & $\begin{array}{c}0.035 \\
(0.031)\end{array}$ & $\begin{array}{l}0.030 \\
(0.031)\end{array}$ & $\begin{array}{l}0.024 \\
(0.044)\end{array}$ \\
\hline \multicolumn{8}{|l|}{ Dep. Var.: $\operatorname{Pr}\left(\zeta_{i j r c t}=1\right)$} \\
\hline Firm size & $\begin{array}{l}-0.0081 \\
(0.0057)\end{array}$ & $\begin{array}{l}-0.0081 \\
(0.0057)\end{array}$ & $\begin{array}{l}-0.0081 \\
(0.0057)\end{array}$ & $\begin{array}{l}-0.0082 \\
(0.0057)\end{array}$ & $\begin{array}{c}-0.011 \\
(0.0084)\end{array}$ & $\begin{array}{c}-0.011 \\
(0.0084)\end{array}$ & $\begin{array}{l}-0.016^{*} \\
(0.0096)\end{array}$ \\
\hline Firm age & $\begin{array}{l}0.37^{* * *} \\
(0.015)\end{array}$ & $\begin{array}{l}0.37^{* * *} \\
(0.015)\end{array}$ & $\begin{array}{c}0.37^{* * *} \\
(0.015)\end{array}$ & $\begin{array}{l}0.37^{* * *} \\
(0.015)\end{array}$ & $\begin{array}{c}0.37^{* * *} \\
(0.016)\end{array}$ & $\begin{array}{c}0.37^{* * *} \\
(0.016)\end{array}$ & $\begin{array}{c}0.47^{* * *} \\
(0.018)\end{array}$ \\
\hline Foreign & $\begin{array}{l}-0.020^{*} \\
(0.011)\end{array}$ & $\begin{array}{c}-0.020^{*} \\
(0.011)\end{array}$ & $\begin{array}{c}-0.020^{*} \\
(0.011)\end{array}$ & $\begin{array}{c}-0.019^{*} \\
(0.011)\end{array}$ & $\begin{array}{l}-0.022 \\
(0.013)\end{array}$ & $\begin{array}{l}-0.022 \\
(0.013)\end{array}$ & $\begin{array}{l}-0.017 \\
(0.015)\end{array}$ \\
\hline Constant & $\begin{array}{l}-0.090 \\
(0.070)\end{array}$ & $\begin{array}{l}-0.090 \\
(0.070)\end{array}$ & $\begin{array}{c}-0.090 \\
(0.070)\end{array}$ & $\begin{array}{l}-0.091 \\
(0.070)\end{array}$ & $\begin{array}{l}-0.19 \\
(0.12)\end{array}$ & $\begin{array}{l}-0.19 \\
(0.12)\end{array}$ & $\begin{array}{c}-0.56^{* * *} \\
(0.14)\end{array}$ \\
\hline athrho & $\begin{array}{c}0.023^{* * *} \\
(0.0063)\end{array}$ & $\begin{array}{c}0.022^{* * *} \\
(0.0064)\end{array}$ & $\begin{array}{c}0.024 * * * \\
(0.0064)\end{array}$ & $\begin{array}{c}0.025^{* * *} \\
(0.0065)\end{array}$ & $\begin{array}{c}0.029 * * * \\
(0.0075)\end{array}$ & $\begin{array}{c}0.029^{* * *} * \\
(0.0075)\end{array}$ & $\begin{array}{c}0.027 * * * \\
(0.0084)\end{array}$ \\
\hline lnsigma & $\begin{array}{c}-0.29^{* * *} \\
(0.022)\end{array}$ & $\begin{array}{c}-0.29^{* * *} \\
(0.022)\end{array}$ & $\begin{array}{c}-0.29^{* * *} \\
(0.022)\end{array}$ & $\begin{array}{c}-0.29^{* * *} \\
(0.022)\end{array}$ & $\begin{array}{c}-0.27^{* * *} \\
(0.023)\end{array}$ & $\begin{array}{c}-0.27^{* * *} \\
(0.023)\end{array}$ & $\begin{array}{c}-0.34^{* * *} \\
(0.024)\end{array}$ \\
\hline Observations & $2,550,874$ & $2,550,874$ & $2,550,874$ & $2,546,056$ & $2,120,853$ & $2,120,853$ & $1,771,665$ \\
\hline NUTS-2 regions & 273 & 273 & 273 & 273 & 273 & 273 & 273 \\
\hline Log likelihood & -3524182.4 & -3523697.2 & -3523341.7 & -3517316.6 & -2942606.2 & -2942605.1 & -2317468.8 \\
\hline Rho & 0.023 & 0.022 & 0.024 & 0.025 & 0.029 & 0.029 & 0.027 \\
\hline Sigma & 0.75 & 0.75 & 0.75 & 0.75 & 0.76 & 0.76 & 0.71 \\
\hline Lambda & 0.017 & 0.017 & 0.018 & 0.019 & 0.022 & 0.022 & 0.019 \\
\hline Wald chi2 & $13.6(1)$ & $12.0(1)$ & $13.9(1)$ & $15.1(1)$ & $15.0(1)$ & $15.0(1)$ & $10.5(1)$ \\
\hline Prob $>$ chi 2 & 0.00022 & 0.00053 & 0.00020 & 0.00010 & 0.00011 & 0.00011 & 0.0012 \\
\hline Year dummies & NO & YES & YES & YES & YES & YES & YES \\
\hline
\end{tabular}

Cluster by region. Robust standard errors in parentheses ${ }^{* * *} p<0.01,{ }^{* *} p<0.05,{ }^{*} p<0.1$. 
Table 6: Robustness of findings across the percentiles of the TFP distribution.

\begin{tabular}{|c|c|c|c|c|c|c|}
\hline Dep. Var.: $\Delta\left(t f p_{i j r t}\right)$ & $\mathrm{p} 25$ & p50 & p75 & p90 & p95 & p99 \\
\hline$t f p_{i j r t, t-1}$ & $\begin{array}{c}-0.075^{* * *} \\
(0.0053)\end{array}$ & $\begin{array}{c}-0.032^{* * *} \\
(0.0035)\end{array}$ & $\begin{array}{c}-0.020^{* * *} \\
(0.0022)\end{array}$ & $\begin{array}{c}-0.013^{* * *} \\
(0.0013)\end{array}$ & $\begin{array}{c}-0.012^{* * *} \\
(0.0011)\end{array}$ & $\begin{array}{c}-0.010^{* * *} \\
(0.0010)\end{array}$ \\
\hline ERDF Business support & $\begin{array}{c}-0.018^{* * *} \\
(0.0047)\end{array}$ & $\begin{array}{c}-0.0069^{* * *} \\
(0.0015)\end{array}$ & $\begin{array}{c}-0.0041^{* * *} \\
(0.00089)\end{array}$ & $\begin{array}{c}-0.0024^{* * *} \\
(0.00065)\end{array}$ & $\begin{array}{c}-0.0020^{* * *} \\
(0.00057)\end{array}$ & $\begin{array}{c}-0.0017^{* * *} * \\
(0.00051)\end{array}$ \\
\hline ERDF $R T D$ & $\begin{array}{c}0.014^{* *} \\
(0.0061)\end{array}$ & $\begin{array}{c}0.0067^{* * *} \\
(0.0021)\end{array}$ & $\begin{array}{c}0.0044^{* * *} \\
(0.0012)\end{array}$ & $\begin{array}{c}0.0023^{* * *} \\
(0.00088)\end{array}$ & $\begin{array}{l}0.0016^{* *} \\
(0.00077)\end{array}$ & $\begin{array}{c}0.0014^{*} \\
(0.00072)\end{array}$ \\
\hline Firm size & $\begin{array}{c}-0.14^{* * *} \\
(0.016)\end{array}$ & $\begin{array}{c}-0.050^{* * *} \\
(0.0066)\end{array}$ & $\begin{array}{c}-0.024^{* * *} \\
(0.0039)\end{array}$ & $\begin{array}{c}-0.013^{* * *} \\
(0.0026)\end{array}$ & $\begin{array}{c}-0.012^{* * *} \\
(0.0024)\end{array}$ & $\begin{array}{c}-0.0081^{* * *} \\
(0.0022)\end{array}$ \\
\hline N. of employees & $\begin{array}{c}0.22^{* * *} \\
(0.016)\end{array}$ & $\begin{array}{c}0.087^{* * *} \\
(0.0078)\end{array}$ & $\begin{array}{c}0.046^{* * *} \\
(0.0042)\end{array}$ & $\begin{array}{c}0.026^{* * *} \\
(0.0029)\end{array}$ & $\begin{array}{c}0.024^{* * *} \\
(0.0026)\end{array}$ & $\begin{array}{c}0.021^{* * *} \\
(0.0024)\end{array}$ \\
\hline Regional gdp in millions Euro & $\begin{array}{l}0.049^{*} \\
(0.025)\end{array}$ & $\begin{array}{c}0.013 \\
(0.0080)\end{array}$ & $\begin{array}{c}0.0034 \\
(0.0034)\end{array}$ & $\begin{array}{c}0.0072^{* * *} \\
(0.0020)\end{array}$ & $\begin{array}{c}0.0074^{* * *} \\
(0.0020)\end{array}$ & $\begin{array}{c}0.0057^{* * * *} \\
(0.0019)\end{array}$ \\
\hline \% Aged 25-64 (Education levels 3-4) & $\begin{array}{c}0.0015 \\
(0.0019)\end{array}$ & $\begin{array}{c}0.00040 \\
(0.00053)\end{array}$ & $\begin{array}{l}-0.00033 \\
(0.00026)\end{array}$ & $\begin{array}{l}-0.00026 \\
(0.00021)\end{array}$ & $\begin{array}{l}-0.00030 \\
(0.00018)\end{array}$ & $\begin{array}{c}-0.00031^{*} \\
(0.00016)\end{array}$ \\
\hline \% Aged 25-64 (Education levels 5-8) & $\begin{array}{c}0.0023 \\
(0.0027)\end{array}$ & $\begin{array}{c}0.0022^{* * *} \\
(0.00078)\end{array}$ & $\begin{array}{c}0.00047 \\
(0.00034)\end{array}$ & $\begin{array}{l}0.000093 \\
(0.00023)\end{array}$ & $\begin{array}{l}0.000098 \\
(0.00021)\end{array}$ & $\begin{array}{l}0.000084 \\
(0.00019)\end{array}$ \\
\hline Agglomeration & $\begin{array}{c}0.0065 \\
(0.0052)\end{array}$ & $\begin{array}{r}-0.00031 \\
(0.0026)\end{array}$ & $\begin{array}{c}-0.00081 \\
(0.0017)\end{array}$ & $\begin{array}{l}-0.0019 \\
(0.0015)\end{array}$ & $\begin{array}{c}-0.0037^{* *} \\
(0.0017)\end{array}$ & $\begin{array}{c}-0.0041^{* *} \\
(0.0017)\end{array}$ \\
\hline Specialization & $\begin{array}{c}-9.36^{* * *} \\
(1.32)\end{array}$ & $\begin{array}{c}-4.83^{* * *} \\
(0.80)\end{array}$ & $\begin{array}{c}-2.60 * * * \\
(0.44)\end{array}$ & $\begin{array}{c}-0.78^{* * *} \\
(0.17)\end{array}$ & $\begin{array}{c}-0.32^{* * *} \\
(0.11)\end{array}$ & $\begin{array}{l}-0.065 \\
(0.078)\end{array}$ \\
\hline Diversification & $\begin{array}{c}3.07^{* * *} \\
(1.04)\end{array}$ & $\begin{array}{c}1.34^{* * *} \\
(0.46)\end{array}$ & $\begin{array}{c}0.68^{* * *} \\
(0.26)\end{array}$ & $\begin{array}{c}0.16 \\
(0.15)\end{array}$ & $\begin{array}{l}0.017 \\
(0.12)\end{array}$ & $\begin{array}{l}-0.11 \\
(0.10)\end{array}$ \\
\hline Competition & $\begin{array}{c}-1.17^{* * *} \\
(0.28)\end{array}$ & $\begin{array}{c}0.040 \\
(0.051)\end{array}$ & $\begin{array}{c}-0.088^{* *} \\
(0.038)\end{array}$ & $\begin{array}{c}-0.073^{* * *} \\
(0.028)\end{array}$ & $\begin{array}{c}-0.057^{* *} \\
(0.027)\end{array}$ & $\begin{array}{l}-0.040^{*} \\
(0.024)\end{array}$ \\
\hline Constant & $\begin{array}{c}0.74^{* *} \\
(0.37)\end{array}$ & $\begin{array}{c}0.35^{* * *} \\
(0.10)\end{array}$ & $\begin{array}{c}0.27^{* * *} \\
(0.059)\end{array}$ & $\begin{array}{c}0.098^{* *} \\
(0.040)\end{array}$ & $\begin{array}{c}0.082^{* *} \\
(0.036)\end{array}$ & $\begin{array}{c}0.049 \\
(0.032)\end{array}$ \\
\hline \multicolumn{7}{|l|}{ Dep. Var.: $\operatorname{Pr}\left(\zeta_{\text {ijrct }}=1\right)$} \\
\hline Firm size & $\begin{array}{l}-0.015^{*} \\
(0.0089)\end{array}$ & $\begin{array}{l}-0.016^{*} \\
(0.0081)\end{array}$ & $\begin{array}{c}-0.011 \\
(0.0078)\end{array}$ & $\begin{array}{c}-0.012 \\
(0.0085)\end{array}$ & $\begin{array}{c}-0.012 \\
(0.0085)\end{array}$ & $\begin{array}{c}-0.011 \\
(0.0085)\end{array}$ \\
\hline Firm age & $\begin{array}{c}0.37^{* * *} \\
(0.019)\end{array}$ & $\begin{array}{c}0.38^{* * *} \\
(0.018)\end{array}$ & $\begin{array}{c}0.37^{* * *} \\
(0.017)\end{array}$ & $\begin{array}{l}0.37^{* * *} \\
(0.016)\end{array}$ & $\begin{array}{c}0.37^{* * *} \\
(0.016)\end{array}$ & $\begin{array}{c}0.37^{* * *} \\
(0.016)\end{array}$ \\
\hline Foreign & $\begin{array}{c}0.011 \\
(0.015)\end{array}$ & $\begin{array}{l}-0.019 \\
(0.015)\end{array}$ & $\begin{array}{l}-0.013 \\
(0.014)\end{array}$ & $\begin{array}{l}-0.021 \\
(0.014)\end{array}$ & $\begin{array}{c}-0.024^{*} \\
(0.014)\end{array}$ & $\begin{array}{c}-0.023^{*} \\
(0.013)\end{array}$ \\
\hline Constant & $\begin{array}{l}-0.13 \\
(0.12)\end{array}$ & $\begin{array}{l}-0.13 \\
(0.11)\end{array}$ & $\begin{array}{l}-0.19^{*} \\
(0.11)\end{array}$ & $\begin{array}{l}-0.19 \\
(0.12)\end{array}$ & $\begin{array}{l}-0.19 \\
(0.12)\end{array}$ & $\begin{array}{l}-0.19 \\
(0.12)\end{array}$ \\
\hline athrho & $\begin{array}{c}-0.059^{* *} \\
(0.024)\end{array}$ & $\begin{array}{c}-0.025^{* *} \\
(0.012)\end{array}$ & $\begin{array}{l}-0.014^{*} \\
(0.0072)\end{array}$ & $\begin{array}{c}0.013^{*} \\
(0.0066)\end{array}$ & $\begin{array}{c}0.023^{* * *} \\
(0.0071)\end{array}$ & $\begin{array}{c}0.027^{* * *} \\
(0.0073)\end{array}$ \\
\hline lnsigma & $\begin{array}{l}0.22^{* * *} \\
(0.024)\end{array}$ & $\begin{array}{c}-0.045^{* *} \\
(0.022)\end{array}$ & $\begin{array}{c}-0.20^{* * *} \\
(0.023)\end{array}$ & $\begin{array}{c}-0.25^{* * *} \\
(0.023)\end{array}$ & $\begin{array}{c}-0.27^{* * *} \\
(0.023)\end{array}$ & $\begin{array}{c}-0.28^{* * *} \\
(0.023)\end{array}$ \\
\hline Observations & 534,931 & $1,060,596$ & $1,591,248$ & $1,908,476$ & $2,014,633$ & $2,099,649$ \\
\hline NUTS-2 regions & 273 & 273 & 273 & 273 & 273 & 273 \\
\hline Rho & -0.059 & -0.025 & -0.014 & 0.013 & 0.023 & 0.027 \\
\hline Sigma & 1.25 & 0.96 & 0.82 & 0.78 & 0.77 & 0.76 \\
\hline Lambda & -0.073 & -0.024 & -0.011 & 0.0099 & 0.017 & 0.020 \\
\hline Log likelihood & -935435.5 & -1648000.3 & -2297321.7 & -2676388.3 & -2803628.5 & -2907369.3 \\
\hline Wald chi2 & $5.77(1)$ & $4.26(1)$ & $3.73(1)$ & $3.67(1)$ & $10.2(1)$ & $13.4(1)$ \\
\hline Prob $>$ chi2 2 & 0.016 & 0.039 & 0.053 & 0.055 & 0.0014 & 0.00025 \\
\hline
\end{tabular}


In fact, the distribution that we find for the TFP of EU firms suggests that the average effect of ERDF financial support on firms' productivity growth could deliver a distorted picture of what really happens on the field. Table 6 shows that the strongest impact of regional policy financing is on firms within the $25^{t h}$ percentile, while at the $99^{t h}$ percentile the coefficients reduce and lose significance. That is, already efficient firms are not affected by 'cohesion policy', whereas lowperforming firms seem to experience a downturn in productivity in regions where a significant share of funds is allocated to the category Business Support. By contrast, improvements are observed in the performance of firms with a low initial productivity level when we focus on the share of spending according to the RTD criteria. In addition, we observe that in some percentiles regional-industrial market structures measured as the knowledge spillovers externalities based on the literature on economic geography matter for the growth of TFP. The coefficient of Agglomeration is negative and significant at the $95^{\text {th }}$ and $99^{t h}$ percentiles. Also, the employment density of an industry in the region, i.e. Specialisation, decreases the TFP growth up to the $95^{\text {th }}$ percentile.

Indeed, the industrial mix within a region, i.e. Diversification of other industries in the region, suggests that less industrial diversity is likely to improve the growth of firm productivity positively. This result contradicts the theory of Jacobs (1969) that diversification of various industries resulting in urbanisation potentially fosters the growth of cities. However, it is attaining the results of empirical studies by Glaeser et al. (1992), and by van der Panne and van Beers (2006) on local industrial innovation in the Netherlands.

Finally, we find that competition measured as the inverse of average employment at local units within the regional industry has a negative and statistically significant impact on low-performing firms.

\section{Conclusions}

In this contribution, we introduce a novel firm-level total factor productivity database, where a 'continental' approach is adopted in the estimations by industry across the Wider Europe, including the EU28 plus the Western Balkan countries. We find empirical evidence of heterogeneity in firm performance in all countries, regions, and within industries, confirming the existence of considerable dispersion that is well-documented and widely accepted in the corresponding literature.

When discussing policy-making in Europe, the tendency is to refer to aggregate country-, regionor industry-level data as these are easier to calculate, understand, and finally communicate (Altomonte et al., 2012). However, there are actually firms that shape the aggregate statistics through their daily activity of investing, producing, selling and exporting. The last decade of empirical studies on firm-level data shows how no 'average' firm within an industry, a region or a country can represent the aggregates (among others, see for example Mayer and Ottaviano (2008)). Firms are heterogeneous along many dimensions, and their distributions have power-law right tails.

Therefore, we enrich the empirical literature with an assessment of the impact of regional policies mandated at the EU level on the productivity of firms. European Regional Development Fund 
(ERDF) for Business Support, and Research, Technology, and Development (RTD) are the relevant priorities that we take into consideration as main policy variables affecting firm-level TFP growth in the EU. Results show that financing of 'cohesion policy' (ERDF) aimed at direct investments in R\&D correlates with improvement of firms' productivity in a region during the period 2007-2015. Conversely, funding designed at overall Business Support correlates with negative productivity growth rates. This might indicate that these funds are not efficiently allocated to the firms with prosperous future. In fact, those funds could be directed to the inefficient firms as their potential saviours. In both cases, we registered an asymmetric impact along the firms' productivity distributions. Eventually, our contribution showed that a consideration of the heterogeneous characteristics of the potential beneficiaries of EU funds across regions is of paramount importance for the design of effective and efficient policies of regional convergence.

Future research should overcome the policy data limitations at the firm-level. For the programming period 2014-2020, improvements in the administrative capacity and coordination by public administration in member states and regions is expected. Therefore, data on individual projects, such as expenditure, category, and beneficiaries should be available in a more harmonised way across European regions. Then, this detailed information could be integrated with other firm-level characteristics to evaluate the impact of the 'cohesion policy' also on the productivity of individual firms. 


\section{References}

Ackerberg, D., Caves, K., and Frazer, G. (2015). Identification Properties of Recent Production Function Estimators. Econometrica, 83(6):2411-2451.

Altomonte, C., Aquilante, T., and Ottaviano, G. (2012). The triggers of competitiveness: the EFIGE cross-country report. Bruegel Blueprint 17.

Altomonte, C., Nicolini, M., Rungi, A., and Ogliari, L. (2010). Assessing the Competitive Behaviour of Firms in the Single Market: A Micro-based Approach. Economic papers, European Economy.

Bartelsman, E. J. and Doms, M. (2000). Understanding Productivity: Lessons from Longitudinal Microdata. Journal of Economic Literature, 38(3):569-594.

Bartelsman, E. J., Haltiwanger, J., and Scarpetta, S. (2013). Cross-Country Differences in Productivity: The Role of Allocation and Selection. American Economic Review, 103(1):305-34.

Beaudry, C. and Schiffauerova, A. (2009). Who's right, Marshall or Jacobs? The localization versus urbanization debate. Research policy, 38(2):318-337.

Bergström, F. (2000). Capital Subsidies and the Performance of Firms. Small Business Economics, 14(3):183-193.

Bernini, C. and Pellegrini, G. (2011). How are growth and productivity in private firms affected by public subsidy? Evidence from a regional policy. Regional Science and Urban Economics, 41(3):253-265.

Boldrin, M. and Canova, F. (2001). Inequality and Convergence in Europe's Regions: Reconsidering European Regional Policies. Economic policy, 16(32):206-253.

Cappelen, A., Castellacci, F., Fagerberg, J., and Verspagen, B. (2003). The Impact of EU Regional Support on Growth and Convergence in the European Union. Journal of Common Market Studies, 41(4):621-644.

Collard-Wexler, A. and De Loecker, J. (2016). Production Function Estimation with Measurement Error in Inputs. Working paper, National Bureau of Economic Research.

Dall'Erba, S. and Le Gallo, J. (2008). Regional covergence and the impact of european structural funds over 1989-1999: A spatial econometric analysis. Papers in Regional Science, 87(2):219-244.

De Lucio, J. J., Herce, J. A., and Goicolea, A. (2002). The Effects of Externalities on Productivity Growth in Spanish Industry. Regional Science and Urban Economics, 32(2):241-258.

De Zwann, M. and Merlevede, B. (2013). Regional policy and firm productivity. ETSG 2013, 377.

Ederveen, S., Gorter, J., De Mooij, R., and Nahuis, R. (2003). Funds and games: the economics of european cohesion policy. Technical report, European Network of Economic Policy Research Institutes.

European Commission (2010). Europe 2020. A strategy for smart, sustainable and inclusive growth. Communication from the Commission. COM (2010) 2020 final.

European Commission (2017). 7th Report on Economic, Social and Territorial Cohesion. Technical report, European Commission.

Foster, L., Grim, C., Haltiwanger, J., and Wolf, Z. (2016). Firm-Level Dispersion in Productivity: Is the Devil in the Details? American Economic Review, 106(5):95-98. 
Gal, P. N. (2013). Measuring Total Factor Productivity at the Firm Level using OECD-ORBIS. OECD Publishing.

Glaeser, E. L., Kallal, H. D., Scheinkman, J. A., and Shleifer, A. (1992). Growth in Cities. Journal of Political Economy, 100(6):1126-1152.

Harris, R. and Trainor, M. (2005). Capital Subsidies and their Impact on Total Factor Productivity: Firm-level Evidence from Northern Ireland. Journal of Regional Science, 45(1):49-74.

Hartsenko, J. and Sauga, A. (2012). Does financial support from the EU structural funds has an impact on the firms' performance: Evidence from Estonia. In Proceedings of 30th International Conference Mathematical Methods in Economics, pages 260-65.

Heckman, J. J. (1976). The Common Structure of Statistical Models of Truncation, Sample Selection and Limited Dependent Variables and a Simple Estimator for such Models. Annals of Economic and Social Measurement, 5(4):475-492.

Heckman, J. J. (1979). Sample Selection Bias as a Specification Error. Econometrica, 47(1):153-161.

Henderson, V., Kuncoro, A., and Turner, M. (1995). Industrial Development in Cities.. Journal of political economy, 103(5):1067-1090.

Hsieh, C. T. and Klenow, P. J. (2009). Misallocation and Manufacturing TFP in China and India. The Quarterly Journal of Economics, 124(4):1403-1448.

Hulten, C. R. (2001). Total Factor Productivity: A Short Biography, pages 1-54. University of Chicago Press.

Jacobs, J. (1969). The Economy of Cities. Vintage Books.

Kalemli-Ozcan, S., Sorensen, B., Villegas-Sanchez, C., Volosovych, V., and Yesiltas, S. (2015). How to Construct Nationally Representative Firm Level data from the ORBIS Global Database. Working paper, National Bureau of Economic Research.

Katayama, H., Lu, S., and Tybout, J. R. (2009). Firm-level Productivity Studies: Illusions and a Solution. International Journal of Industrial Organization, 27(3):403-413.

Klette, T. J. and Griliches, Z. (1996). The Inconsistency of Common Scale Estimators when Output Prices are Unobserved and Endogenous. Journal of Applied Econometrics, 11(4):343-361.

Krugman, P. (1991). Increasing Returns and Economic Geography. Journal of Political Economy, 99(3):483-499.

Leonardi, R. (2006). Cohesion in the European Union. Regional Studies, 40(2):155-166.

Marschak, J. and Andrews, W. H. (1944). Random Simultaneous Equations and the Theory of Production. Econometrica, 12(3/4):143-205.

Mayer, T. and Ottaviano, G. (2008). The happy few: The internationalisation of european firms. Intereconomics, 43(3):135-148.

Olley, G. S. and Pakes, A. (1996). The Dynamics of Productivity in the Telecommunications Equipment Industry. Econometrica, 64(6):1263-1297.

Ribeiro, S. P., Menghinello, S., and De Backer, K. (2010). The OECD ORBIS Database: Responding to the Need for Firm-level Micro-data in the OECD. OECD Statistics Working Papers.

Silverman, B. W. (1986). Density estimation for statistics and data analysis, volume 26. CRC press. 
Smarzynska Javorcik, B. (2004). Does Foreign Direct Investment Increase the Productivity of Domestic Firms? In Search of Spillovers Through Backward Linkages. American Economic Review, 94(3):605-627.

Syverson, C. (2004a). Market Structure and Productivity: A Concrete Example. Journal of Political Economy, 112(6):1181-1222.

Syverson, C. (2004b). Product Substitutability and Productivity Dispersion. The Review of Economics and Statistics, 86(2):534-550.

Syverson, C. (2011). What Determines Productivity? Journal of Economic Literature, 49(2):326365.

Timmer, M. P., Los, B., Stehrer, R., and de Vries, G. J. (2016). An Anatomy of the Global Trade Slowdown based on the WIOD 2016 Release. GGDC Research Memorandum GD-162, Groningen Growth and Development Centre, University of Groningen.

Van Beveren, I. (2012). Total Factor Productivity Estimation: A Practical Review. Journal of Economic Surveys, 26(1):98-128.

van der Panne, G. and van Beers, C. (2006). On the Marshall--Jacobs Controversy: It Takes Two to Tango. Industrial and Corporate Change, 15(5):877-890.

wiiw and ISMERI EUROPA (2015). Geography of Expenditure Final Report Work Package 13 - Ex post evaluation of Cohesion Policy programmes 2007-2013, focusing on the European Regional Development funds (ERDF) and the Cohesion Fund. Technical report, European Commission. 


\section{A Tables and Graphs Appendix}

Table A1: Industry classification - Manufacturing.

\begin{tabular}{ll}
\hline \hline Code & 2-digit NACE rev.2 \\
\hline $\mathbf{1 0}$ & Manufacture of food products \\
$\mathbf{1 1}$ & Manufacture of beverages \\
$\mathbf{1 2}$ & Manufacture of tobacco products \\
$\mathbf{1 3}$ & Manufacture of textiles \\
$\mathbf{1 4}$ & Manufacture of wearing apparel \\
$\mathbf{1 5}$ & Manufacture of leather and related products \\
$\mathbf{1 6}$ & Manufacture of wood and of products of wood and cork, except furniture; \\
& manufacture of articles of straw and plaiting materials \\
$\mathbf{1 7}$ & Manufacture of paper and paper products \\
$\mathbf{1 8}$ & Printing and reproduction of recorded media \\
$\mathbf{2 0}$ & Manufacture of coke and refined petroleum products \\
$\mathbf{2 1}$ & Manufacture of chemicals and chemical products \\
$\mathbf{2 2}$ & Manufacture of basic pharmaceutical products and pharmaceutical preparations \\
$\mathbf{2 3}$ & Manufacture of rubber and plastic products \\
$\mathbf{2 4}$ & Manufacture of other non-metallic mineral products \\
$\mathbf{2 5}$ & Manufacture of basic metals \\
$\mathbf{2 6}$ & Manufacture of computer, electronic and optical products \\
$\mathbf{2 7}$ & Manufacture of electrical equipment \\
$\mathbf{2 8}$ & Manufacture of machinery and equipment n.e.c. \\
$\mathbf{2 9}$ & Manufacture of motor vehicles, trailers and semi-trailers \\
$\mathbf{3 0}$ & Manufacture of other transport equipment \\
$\mathbf{3 1}$ & Manufacture of furniture \\
$\mathbf{3 2}$ & Other manufacturing \\
$\mathbf{3 3}$ & Repair and installation of machinery and equipment \\
\end{tabular}


Figure A.1: Distribution (log) TFP- ACF by country, 2007 vs. 2015.
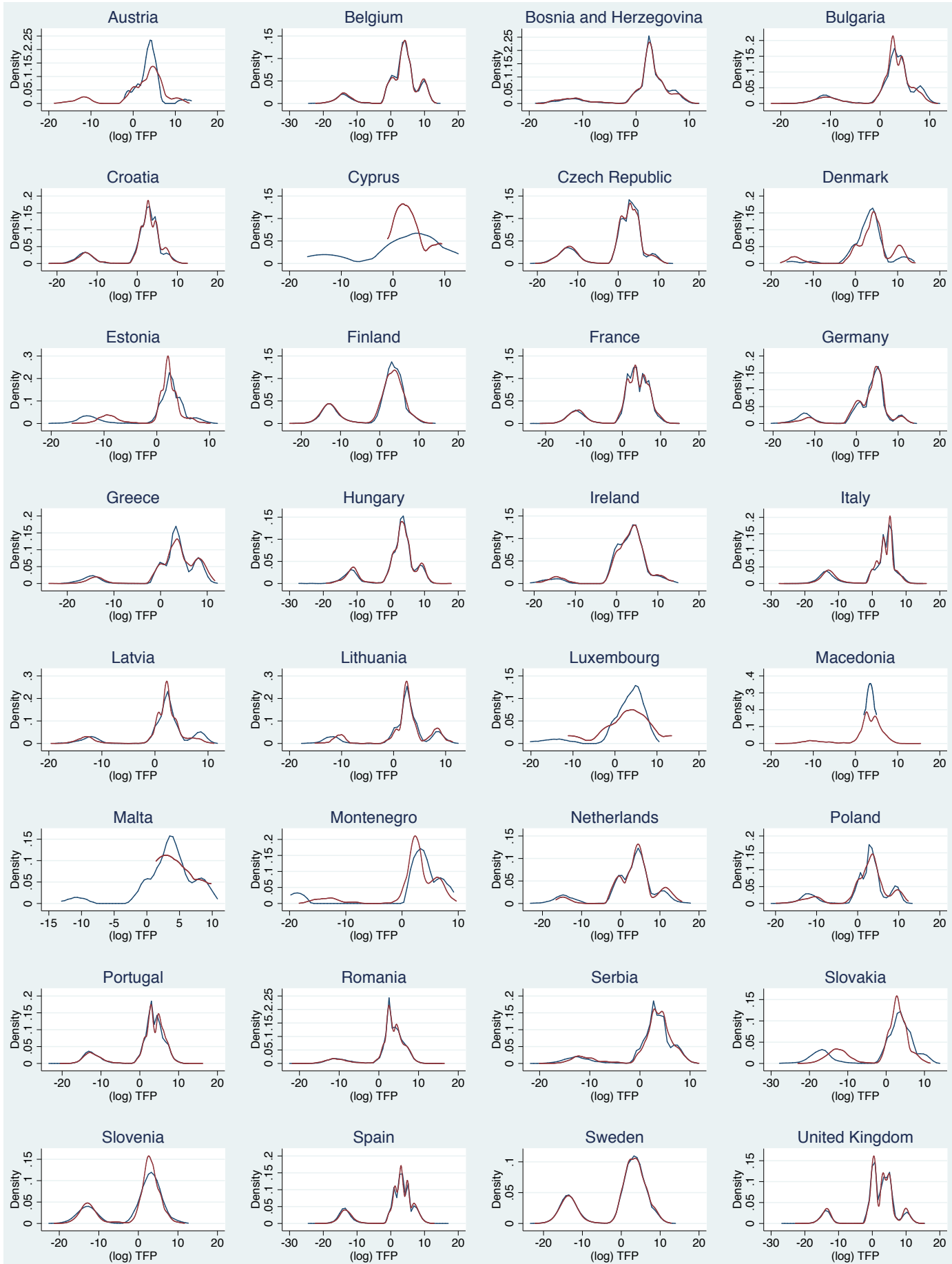

Notes: This Figure presents the firm-level total factor productivity distributions in logarithm for each country in the sample at the beginning and at the end of the sample period. Empirical densities are estimated adopting Epanechnikov kernel, as suggested by Silverman (1986).

Source: Own elaboration. 


\section{B Data Appendix}

ERDF Business Support: Data sourced from the report 'Geography of Expenditure - Work Package 13' prepared for the European Commission in 2015 (wiiw and ISMERI EUROPA, 2015). It is a specified thematic priority of the regional operational programme aimed at supporting firms with the European Regional Development Fund. Financed projects in this category should help firms or groups of firms, in particular, SMEs, with services and investments in innovation and sustainable production. We use payments by NUTS-2 region for the programming period 2007-2013.

ERDF RTD: Data sourced from the report 'Geography of Expenditure - Work Package 13' prepared for the European Commission in 2015 (wiiw and ISMERI EUROPA, 2015). It is a specified thematic priority of the regional operational programme aimed at supporting firms with the European Regional Development Fund. Financed projects in this category should stimulate research and innovation activities through investments in research centres, promoting technology transfers and cooperation between businesses and the scientific environment. We use payments by NUTS-2 region for the programming period 2007-2013.

Firm size: Computed from ORBIS data. It is the turnover in log of the firm $i$ operating in industry $j$ located in region $r$ in year $t$.

N. of employees: Computed from ORBIS data. It is the number of employees in log of the firm $i$ operating in industry $j$ located in region $r$ in year $t$.

Firm age: Computed from ORBIS data. It is the age in log of the firm $i$ operating in industry $j$ located in region $r$ in year $t$.

Foreign: Computed from the ORBIS data. It is a dummy variable equal to 1 if the firm $i$ is a foreign-owned subsidiary and 0 otherwise.

\% Aged 25-64 (Education levels 3-4): Data sourced from the Education and Training database by Eurostat. It is the percentage of people aged 25-64 with upper secondary and postsecondary non-tertiary education (International standard classification of education (ISCED) 2011 levels 3 and 4) by NUTS-2 region.

\% Aged 25-64 (Education levels 5-8): Data sourced from the Education and Training database by Eurostat. It is the percentage of people aged 25-64 with tertiary education (International standard classification of education (ISCED) 2011 levels 5-8) by NUTS-2 region.

Agglomeration: Computed using Structural Business Statistics (SBS) data from Eurostat database. It represents the geographical concentration of the economic activity of the regional

industry. It is measured using the ratio of regional industrial employment to the total local area, following Henderson et al. (1995).

$$
A g l=\frac{L_{j r t}}{A r e a_{r t}}=\frac{\sum_{i} L_{i j r t}}{\text { Areart }}
$$


Specialisation: Computed using Structural Business Statistics (SBS) data from Eurostat database. It captures the level of concentration of the industry in the region. It is measured using the ratio of regional industrial employment to the total regional employment, following Henderson et al. (1995).

$$
S=\frac{L_{j r t}}{\sum_{j} L_{j r t}}=\frac{\sum_{i} L_{i j r t}}{\sum_{j} \sum_{i} L_{i j r t}}
$$

Diversification: Computed using Structural Business Statistics (SBS) data from Eurostat database. It shows the within-regional concentration of industries other than the one under investigation. It is measured by the Hirschman-Herfindahl Index, and it is defined as the sum of squares of the share of other industries' employment in the region relative to the total employment in the region except for the respective industry in question. The value of this index becomes larger when there is a concentration of another activity in the region. It becomes smaller reaching the inverse of many other industries in the region when employment is equally distributed across other regional industries.

$$
D=\sum_{j^{\prime} \neq j} S_{j^{\prime} r t}^{2}=\sum_{j^{\prime} \neq j}\left(\frac{L_{j^{\prime} r t}}{\sum_{j^{\prime} \neq j} L_{j^{\prime} r t}}\right)^{2}
$$

Competition: Computed using Structural Business Statistics (SBS) data from Eurostat database. It captures the competition within the local industry according to the number of local units resulting in the inverse average employment of the local firms.

$$
C=n_{j r t} / L_{j r t}
$$

where $n_{j r t}$ is the number of local units (firms) in the region $r$ at time $t$, operating in industry $j$. 


\section{MT $\begin{aligned} & \text { SCHOOL } \\ & \text { FOR ADVANCED }\end{aligned}$ STUDIES LUCCA}

2018 (c) IMT School for Advanced Studies, Lucca

Piazza San ponziano 6, 55100 Lucca, Italy. www.imtlucca.it 